\title{
Total Synthesis of Hyperforin
}

\section{Supporting Information}

\author{
Chi P. Ting and Thomas J. Maimone* \\ Department of Chemistry, University of California, Berkeley, Berkeley, CA, 94720 \\ maimone@berkeley.edu
}

\section{Table of Contents:}

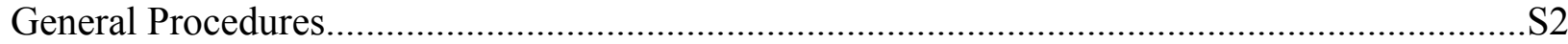

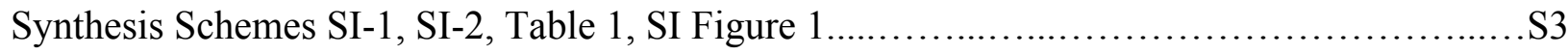

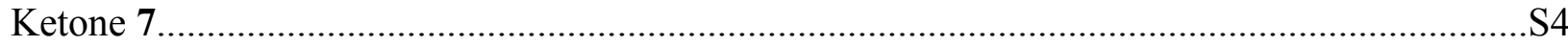

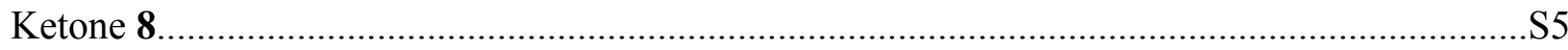

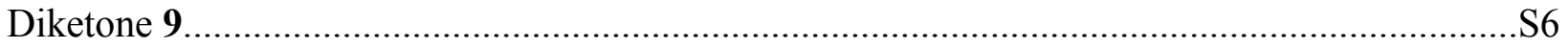

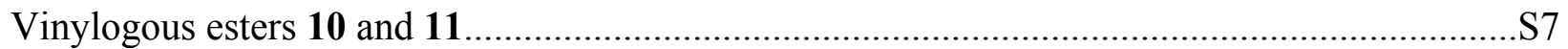

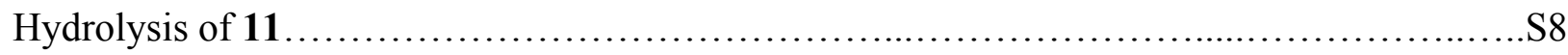

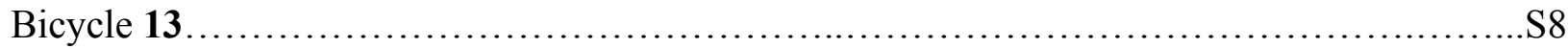

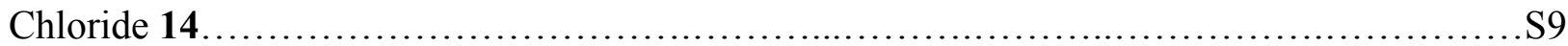

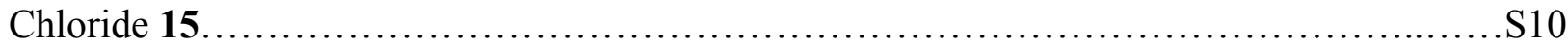

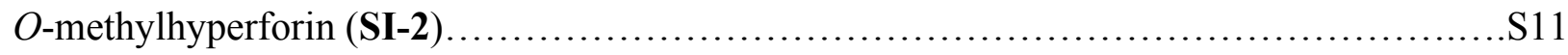

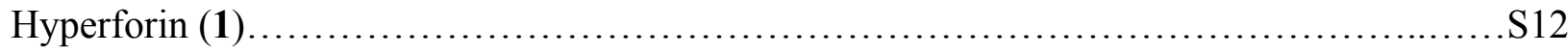

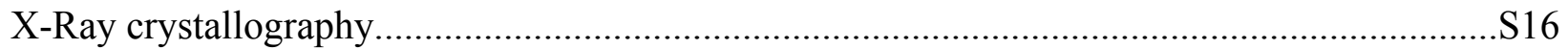

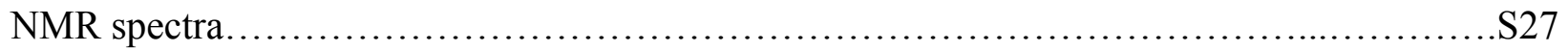




\section{General Procedures}

Unless otherwise stated, all reactions were performed in oven-dried or flame-dried glassware under an atmosphere of dry nitrogen or argon. Dry tetrahydrofuran (THF), dichloromethane, toluene, hexane, acetonitrile, and diethyl ether were obtained by passing these previously degassed solvents through activated alumina columns. Amines and HMPA were distilled from calcium hydride prior to use. Diketene was freshly distilled immediately before use and was colorless. Copper(I) bromide dimethylsulfide complex was stored in a glovebox and small portions removed and manipulated on the benchtop. Lithium chloride was stored in a $160{ }^{\circ} \mathrm{C}$ oven and flame-dried under high vacuum before use. Reactions were monitored by thin layer chromatography (TLC) on Silicycle Siliaplate ${ }^{\mathrm{TM}}$ G TLC plates $(250 \mu \mathrm{m}$ thickness, $60 \AA$ porosity, F-254 indicator) and visualized by UV irradiation and staining with $p$-anisaldehyde, phosphomolybdic acid, or potassium permanganate developing agents. Volatile solvents were removed under reduced pressure using a rotary evaporator. Flash column chromatography was

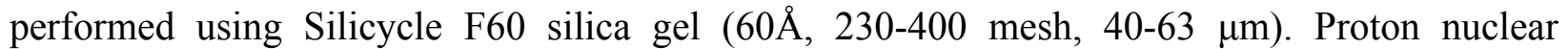
magnetic resonance $\left({ }^{1} \mathrm{H} \mathrm{NMR}\right)$ and carbon nuclear magnetic resonance $\left({ }^{13} \mathrm{C} \mathrm{NMR}\right)$ spectra were recorded on Bruker AVQ-400, AV-500, or AV-600 spectrometers operating respectively at 400, 500, and $600 \mathrm{MHz}$ for ${ }^{1} \mathrm{H}$, and 100,125 , and $150 \mathrm{MHz}$ for ${ }^{13} \mathrm{C}$. Chemical shifts are reported in parts per million (ppm) with respect to the residual solvent signal $\mathrm{CDCl}_{3}\left({ }^{1} \mathrm{H} \mathrm{NMR}: \delta=7.26\right.$; ${ }^{13} \mathrm{C}$ NMR: $\delta=77.16$ ). Peak multiplicities are reported as follows: $\mathrm{s}=$ singlet, bs $=$ broad singlet, $\mathrm{d}=$ doublet, $\mathrm{t}=$ triplet, $\mathrm{dd}=$ doublet of doublets, $\mathrm{td}=$ triplet of doublets, $\mathrm{m}=$ multiplet. app $=$ apparent. Melting points were determined using MEl-TEMPTM apparatus and are uncorrected. IR spectra were recorded on a Nicolet 380 FT-IR spectrometer. High-resolution mass spectra (HRMS) were obtained by the qb3 mass spectrometry facility at the University of California, Berkeley. X-ray crystallographic analyses were performed at the UC-Berkeley College of Chemistry X-ray crystallography facility. 


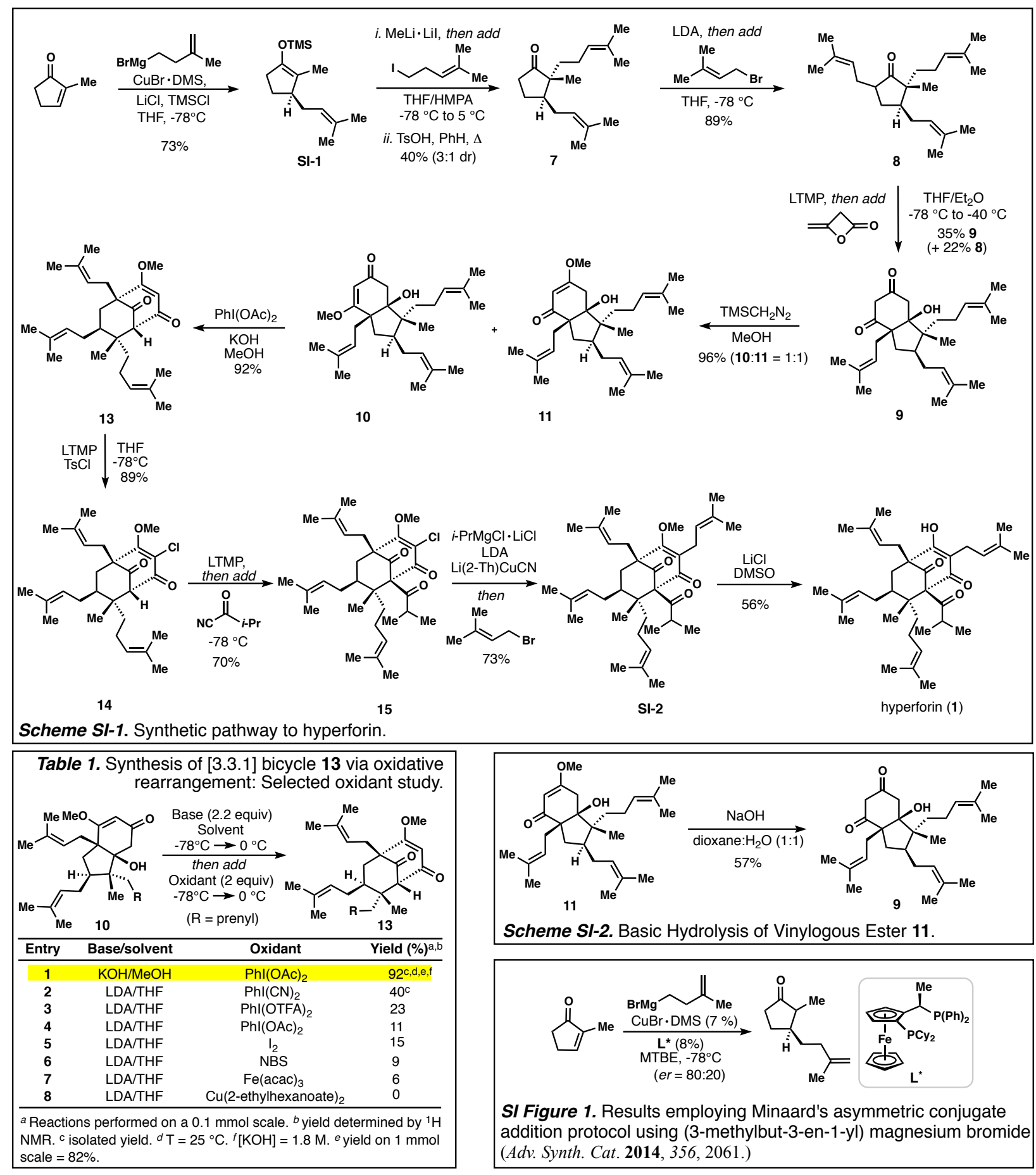




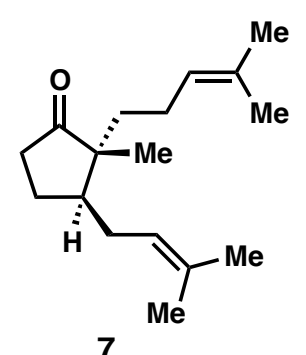

7

Ketone 7. i. A 1 L flame-dried flask was charged with anhydrous lithium chloride (6.6 g, $156 \mathrm{mmol}, 1.2$ equiv) and copper bromide dimethylsulfide complex (32.0 g, $156 \mathrm{mmol}, 1.2$ equiv). The reaction vessel was evacuated and backfilled with nitrogen and this process repeated for a total of three times. THF $(600 \mathrm{~mL})$ was added and the mixture was stirred for 5 minutes at $25^{\circ} \mathrm{C}$ and then cooled to $-78{ }^{\circ} \mathrm{C}$ whereupon (3-methylbut-3-en-1yl)magnesium bromide ( $1 \mathrm{M}$ in $\left.\mathrm{Et}_{2} \mathrm{O}\right), 130 \mathrm{~mL}, 130 \mathrm{mmol}, 1$ equiv) was added dropwise. The resulting dark brown solution was stirred for 30 minutes at $-78{ }^{\circ} \mathrm{C}$ before adding TMSCl $(20.0$ $\mathrm{mL}, 156 \mathrm{mmol}, 1.2$ equiv) and 2-methylcyclopentenone (10.0 g, $104.1 \mathrm{mmol}, 0.8$ equiv) quickly in succession. The reaction mixture was stirred for 60 minutes at $-78{ }^{\circ} \mathrm{C}$ and then triethylamine $(20 \mathrm{~mL})$ was added. The reaction vessel was slowly warmed to $25^{\circ} \mathrm{C}$ over the course of 1 hour and then saturated $a q . \mathrm{NH}_{4} \mathrm{OH} /$ saturated $a q . \mathrm{NH}_{4} \mathrm{Cl}(9: 1 v: v, 200 \mathrm{~mL})$ added, resulting in a dark blue colored solution. The reaction mixture was filtered through Celite, and then extracted with ether $(3 \times 300 \mathrm{~mL})$. The combined organic layers were washed with brine, dried over $\mathrm{MgSO}_{4}$, and concentrated in vacuo. The crude residue was purified by column chromatography $(1 \% \rightarrow$ $2 \% \mathrm{Et}_{2} \mathrm{O}$ in hexanes) to afford the silyl enol ether product SI-1 (18.1 g, 73\% yield) as a colorless oil.

ii. A $250 \mathrm{~mL}$ flame-dried flask was charged with silyl enol ether SI-1 (442 mg, $1.85 \mathrm{mmol}, 1.0$ equiv). The reaction vessel was evacuated and backfilled with nitrogen and this process repeated for a total of three times followed by the addition of THF $(60 \mathrm{~mL})$. After cooling the reaction flask to $0{ }^{\circ} \mathrm{C}$, methyllithium lithium-iodide complex (1.0 M in ether, $2.2 \mathrm{~mL}, 2.20 \mathrm{mmol}, 1.2$ equiv) was added and the reaction mixture was stirred for $1 \mathrm{hr}$. HMPA $(10 \mathrm{~mL})$ was added at $0^{\circ}$ $\mathrm{C}$ followed by cooling to $-78{ }^{\circ} \mathrm{C}$ and the addition of 5-iodo-2-methylpent-2-ene (1.3 mL, 9.25 mmol, 5.0 equiv). The colorless solution was warmed to $5{ }^{\circ} \mathrm{C}$ and stirred for $30 \mathrm{~h}$ at which point it was quenched with deionized $\mathrm{H}_{2} \mathrm{O}(50 \mathrm{~mL})$ and diluted with ether $(100 \mathrm{~mL})$. After organic layer was washed with deionized $\mathrm{H}_{2} \mathrm{O}(2 \times 50 \mathrm{~mL})$. The combined aqueous layers were extracted with ether $(2 \times 100 \mathrm{~mL})$, and the combined organic layers were washed with brine, dried over $\mathrm{MgSO}_{4}$, and concentrated in vacuo to afford a yellow oil. The crude material was dissolved in benzene $(50 \mathrm{~mL})$ under an atmosphere of nitrogen and $p$-toluenesulfonic acid monohydrate (35 $\mathrm{mg}, 0.185 \mathrm{mmol}, 0.1$ equiv) was added. The reaction mixture heated to $70^{\circ} \mathrm{C}$ for $24 \mathrm{~h}$, cooled to 
room temperature, and the brown solution concentrated in vacuo. The crude residue was purified by silica gel column chromatography $\left(1 \% \rightarrow 2 \% \mathrm{Et}_{2} \mathrm{O}\right.$ in hexanes) followed by chromatography on $\mathrm{AgNO}_{3}$ impregnated silica gel $\left(2 \% \mathrm{Et}_{2} \mathrm{O}\right.$ in hexanes) to afford the ketone 7 (184 $\mathrm{mg}, 40 \%$ yield, 3:1 dr) as a yellow oil: ${ }^{1} \mathrm{H}$ NMR $\left(600 \mathrm{MHz}, \mathrm{CDCl}_{3}-d\right) \delta 5.17(\mathrm{t}, J=7.2 \mathrm{~Hz}, 1 \mathrm{H}), 5.04(\mathrm{t}, J$ $=7.1 \mathrm{~Hz}, 1 \mathrm{H}), 2.33(\mathrm{dd}, J=17.2,8.4 \mathrm{~Hz}, 1 \mathrm{H}), 2.18-2.10(\mathrm{~m}, 1 \mathrm{H}), 2.05(\mathrm{~m}, 3 \mathrm{H}), 1.94(\mathrm{~m}, 2 \mathrm{H})$, $1.78-1.72(\mathrm{~m}, 1 \mathrm{H}), 1.71(\mathrm{~s}, 3 \mathrm{H}), 1.65(\mathrm{~s}, 3 \mathrm{H}), 1.63(\mathrm{~s}, 3 \mathrm{H}), 1.62-1.59(\mathrm{~m}, 1 \mathrm{H}), 1.57(\mathrm{~s}, 3 \mathrm{H})$, $1.49-1.39$ (m, 1H), 1.37 (ddd, $J=13.9,11.7,5.0 \mathrm{~Hz}, 1 \mathrm{H}), 0.85(\mathrm{~s}, 3 \mathrm{H}) ;{ }^{13} \mathrm{C}$ NMR $(150 \mathrm{MHz}$, $\left.\left.\mathrm{CDCl}_{3}-d\right)\right) \delta 223.76,132.60,131.76,124.42,122.70,51.46,43.28,37.58,36.11,28.70,25.93$, 25.77, 25.10, 23.44, 17.99, 17.95, 17.71; IR (thin film) 2966, 2924, 2857, 1739, 1451, $1407 \mathrm{~cm}^{-1}$; HRMS (EI) calcd for $\left[\mathrm{C}_{17} \mathrm{H}_{28} \mathrm{O}_{1}\right]: \mathrm{m} / \mathrm{z} 248.2140$, found 248.2142 .

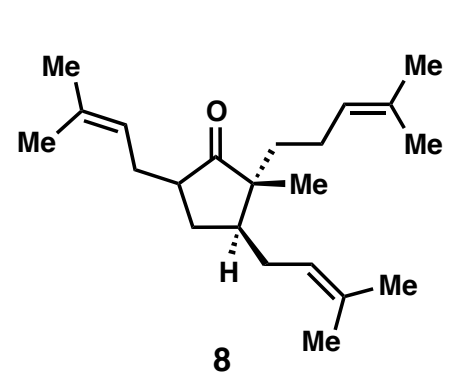

Ketone 8. A $50 \mathrm{~mL}$ flame-dried flask was charged with ketone 7 (440 mg, $1.77 \mathrm{mmol}, 1.0$ equiv). The reaction vessel was evacuated and backfilled with nitrogen (three times in total) followed by the addition of THF $(20 \mathrm{~mL})$. After cooling the reaction vessel to $-78^{\circ} \mathrm{C}$, a freshly prepared solution of lithium diisopropylamide $(0.52 \mathrm{M}$ in THF, $3.60 \mathrm{~mL}, 1.86 \mathrm{mmol}, 1.1$ equiv) was added dropwise via syringe resulting in a light yellow solution. The reaction mixture was stirred for 30 minutes at $78{ }^{\circ} \mathrm{C}$ and then 30 minutes at $0{ }^{\circ} \mathrm{C}$. Dry hexamethylphosphoramide was then added to the reaction mixture at $0{ }^{\circ} \mathrm{C}$ and the mixture re-cooled to $-78^{\circ} \mathrm{C}$. Freshly distilled prenylbromide $\left(0.22 \mathrm{~mL}, 1.95 \mathrm{mmol}, 1.1\right.$ equiv) was added dropwise at $-78{ }^{\circ} \mathrm{C}$ and the resulting pale yellow solution stirred for 15 minutes at this temperature and then warmed to $0{ }^{\circ} \mathrm{C}$, stirred 15 minutes at this temperature, and then quenched with deionized water $(20 \mathrm{~mL})$. The reaction mixture was diluted with ether $(100 \mathrm{~mL})$, and the organic layer was washed with deionized water $(2 \times 20$ $\mathrm{mL})$. The combined aqueous layers were extracted with ether $(2 \times 50 \mathrm{~mL})$. The combined organic layers were washed with brine, dried over $\mathrm{MgSO}_{4}$, and concentrated in vacuo. The crude residue was purified by column chromatography $\left(1 \% \rightarrow 2 \% \mathrm{Et}_{2} \mathrm{O}\right.$ in hexanes) to afford ketone 8 (498 mg, 89\% yield, 13:1 mixture of diastereomers) as a colorless oil: ${ }^{1} \mathrm{H}$ NMR (600 MHz, $\left.\mathrm{CDCl}_{3}-d\right) \delta 5.14(\mathrm{t}, J=6.7 \mathrm{~Hz}, 1 \mathrm{H}), 5.12-5.01(\mathrm{~m}, 2 \mathrm{H}), 2.28(\mathrm{tt}, J=9.0,4.1 \mathrm{~Hz}, 1 \mathrm{H}), 2.22(\mathrm{dt}, J$ $=12.4,5.9 \mathrm{~Hz}, 1 \mathrm{H}), 2.12(\mathrm{dt}, J=12.9,5.9 \mathrm{~Hz}, 1 \mathrm{H}), 2.09-1.99(\mathrm{~m}, 2 \mathrm{H}), 1.94(\mathrm{tt}, J=12.5,5.8$ $\mathrm{Hz}, 1 \mathrm{H}), 1.90-1.82(\mathrm{~m}, 1 \mathrm{H}), 1.81-1.76(\mathrm{~m}, 1 \mathrm{H}), 1.76-1.72(\mathrm{~m}, 1 \mathrm{H}), 1.71(\mathrm{~s}, 3 \mathrm{H}), 1.69(\mathrm{~s}$, 
3H), $1.66(\mathrm{~s}, 3 \mathrm{H}), 1.65-1.63(\mathrm{~m}, 1 \mathrm{H}), 1.62(\mathrm{~s}, 3 \mathrm{H}), 1.60(\mathrm{~s}, 3 \mathrm{H}), 1.58(\mathrm{~s}, 3 \mathrm{H}), 1.55$ (dd, $J=12.7$, $4.8 \mathrm{~Hz}, 1 \mathrm{H}), 1.33(\mathrm{td}, J=13.0,4.9 \mathrm{~Hz}, 1 \mathrm{H}), 0.88(\mathrm{~s}, 3 \mathrm{H}) ;{ }^{13} \mathrm{C} \mathrm{NMR}\left(150 \mathrm{MHz}, \mathrm{CDCl}_{3}-d\right) \delta$ 224.85, 133.57, 132.55, 131.73, 124.46, 122.90, 121.89, 52.35, 46.43, 41.08, 36.03, 29.98, 29.31, 28.71, 25.94, 25.93, 25.80, 23.41, 18.24, 17.99, 17.72; IR (thin film) 2966, 2916, 2858, 1734, 1451, $1376 \mathrm{~cm}$; HRMS (EI) calcd for $\left[\mathrm{C}_{22} \mathrm{H}_{36} \mathrm{O}_{1}\right]: \mathrm{m} / \mathrm{z} 316.2766$, found 316.2763 .

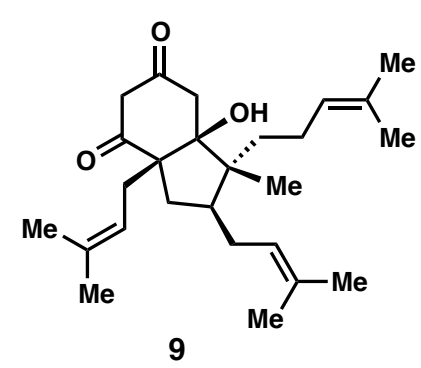

1.2 equiv) was added dropwise resulting in a light yellow colored solution. The reaction mixture was stirred for 30 minutes at $-78^{\circ} \mathrm{C}$ and then 60 minutes at $0{ }^{\circ} \mathrm{C}$. After this period, the reaction mixture was cooled to $-40{ }^{\circ} \mathrm{C}$ and freshly distilled diketene ( $30 \mu \mathrm{L}, 0.38 \mathrm{mmol}, 1.2$ equiv) was rapidly in one portion resulting in a bright yellow solution. The reaction vessel was maintained at this temperature for 90 minutes and then quenched with saturated $a q . \mathrm{NH}_{4} \mathrm{Cl}(20 \mathrm{~mL})$ at this temperature. The reaction mixture was extracted with EtOAc $(3 \times 25 \mathrm{~mL})$ and the combined organic layers were washed with brine, dried over $\mathrm{MgSO}_{4}$, and concentrated in vacuo. The crude residue was purified by column chromatography $\left(5 \% \mathrm{Et}_{2} \mathrm{O}\right.$ in hexanes $\rightarrow 15 \%$ EtOAc in hexanes) to afford the annulated product 9 (44 $\mathrm{mg}, 35 \%$ yield) as a red/orange colored oil and recovered starting material 8 (22 $\mathrm{mg}, 22 \%$ yield). An analytically pure sample of compound 9 could be obtained by cooling a hexanes solution to $-20{ }^{\circ} \mathrm{C}$ wherein a white solid ( $\mathrm{mp}=99-101$ $\left.{ }^{\circ} \mathrm{C}\right)$ precipitates: ${ }^{1} \mathrm{H}$ NMR $\left(600 \mathrm{MHz}, \mathrm{CDCl}_{3}-d\right) \delta 5.11-5.00(\mathrm{~m}, 2 \mathrm{H}), 4.95-4.89(\mathrm{~m}, 1 \mathrm{H}), 3.66$ $(\mathrm{d}, J=18.0 \mathrm{~Hz}, 1 \mathrm{H}), 3.11(\mathrm{~d}, J=18.0 \mathrm{~Hz}, 1 \mathrm{H}), 2.79-2.68(\mathrm{~m}, 2 \mathrm{H}), 2.49$ (dd, $J=15.2,7.0 \mathrm{~Hz}$, $1 \mathrm{H}), 2.46-2.36(\mathrm{~m}, 2 \mathrm{H}), 2.17-2.06(\mathrm{~m}, 2 \mathrm{H}), 2.06-1.97(\mathrm{~m}, 1 \mathrm{H}), 1.94(\mathrm{~s}, 1 \mathrm{H}), 1.80-1.72(\mathrm{~m}$, 1H), $1.68(\mathrm{~s}, 9 \mathrm{H}), 1.62(\mathrm{~s}, 3 \mathrm{H}), 1.59(\mathrm{~s}, 6 \mathrm{H}), 1.41-1.30(\mathrm{~m}, 2 \mathrm{H}), 1.26(\mathrm{t}, J=12.9 \mathrm{~Hz}, 1 \mathrm{H}), 1.17$ $(\operatorname{td}, J=13.2,4.6 \mathrm{~Hz}, 1 \mathrm{H}), 1.02(\mathrm{~s}, 3 \mathrm{H}) ;{ }^{13} \mathrm{C} \mathrm{NMR}\left(150 \mathrm{MHz}, \mathrm{CDCl}_{3}\right) \delta 206.4,203.8,135.2$, $132.5,132.3,124.5,122.8,118.4,84.3,61.2,52.0,50.5,50.4,45.0,37.5,35.2,34.7,29.2,26.2$, 26.0, 25.8, 22.9, 18.3, 18.0, 18.0, 14.9; IR (thin film) 3520, 3375, 2968, 2923, 2878, $1733 \mathrm{~cm}^{-1}$; HRMS (ESI) calcd for $\left[\mathrm{C}_{26} \mathrm{H}_{39} \mathrm{O}_{3}\right]^{-}(\mathrm{M}-\mathrm{H})^{-}: \mathrm{m} / \mathrm{z}$ 399.2905, found 399.2904. 


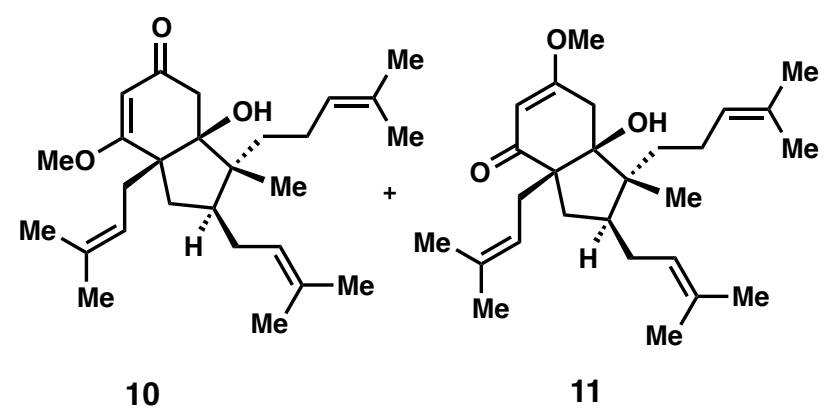

Vinylogous Esters 10 and 11. A flame-dried $50 \mathrm{~mL}$ flask was charged with compound 9 (200 mg, $0.50 \mathrm{mmol}, 1$ equiv). The reaction vessel was evacuated and backfilled with nitrogen (three times in total) followed by the addition of toluene $(16 \mathrm{~mL})$ and methanol $(4$

$\mathrm{mL})$. A solution of trimethylsilyldiazomethane $(2.0 \mathrm{M}$ in hexanes, $0.40 \mathrm{~mL}, 0.75 \mathrm{mmol}, 1.5$ equiv) was added dropwise to the reaction mixture and the resulting yellow solution was stirred for 30 minutes. The reaction mixture was quenched with $a q$. acetic acid (1M solution, $10 \mathrm{~mL}$ ) and extracted with ether $(3 \times 50 \mathrm{~mL})$. The combined organic layers were washed with saturated sodium carbonate, dried over $\mathrm{MgSO}_{4}$, and concentrated in vacuo. The crude residue was purified by column chromatography $(10 \% \rightarrow 20 \%$ EtOAc in hexanes) to afford compound $\mathbf{1 0}$ (100 mg, 48\%) and compound 11 (100 mg, 48\%) both as red/orange oils. Both compounds could be crystallized by cooling hexane solutions to $-20{ }^{\circ} \mathrm{C}$, (compound 10 , white solid, $\mathrm{mp}=83-84{ }^{\circ} \mathrm{C}$; compound 11, white solid, $\left.\mathrm{mp}=85-86{ }^{\circ} \mathrm{C}\right)$. Regioisomer 11: ${ }^{1} \mathrm{H}$ NMR $\left(600 \mathrm{MHz}, \mathrm{CDCl}_{3}-d\right) \delta$ $5.38(\mathrm{~s}, 1 \mathrm{H}), 5.16-5.04(\mathrm{~m}, 2 \mathrm{H}), 4.93(\mathrm{t}, J=7.0 \mathrm{~Hz}, 1 \mathrm{H}), 3.68(\mathrm{~s}, 3 \mathrm{H}), 2.64(\mathrm{~d}, J=17.9 \mathrm{~Hz}$, 1H), $2.60(\mathrm{dd}, J=13.2,7.8 \mathrm{~Hz}, 1 \mathrm{H}), 2.48(\mathrm{dd}, J=14.7,6.5 \mathrm{~Hz}, 1 \mathrm{H}), 2.43(\mathrm{~d}, J=18.0 \mathrm{~Hz}, 1 \mathrm{H})$, $2.36(\mathrm{dd}, J=14.6,8.4 \mathrm{~Hz}, 1 \mathrm{H}), 2.10-2.03(\mathrm{~m}, 1 \mathrm{H}), 2.00-1.91(\mathrm{~m}, 1 \mathrm{H}), 1.90(\mathrm{~s}, 1 \mathrm{H}), 1.89-$ $1.82(\mathrm{~m}, 2 \mathrm{H}), 1.67(\mathrm{~s}, 3 \mathrm{H}), 1.66(\mathrm{~s}, 3 \mathrm{H}), 1.63(\mathrm{~s}, 3 \mathrm{H}), 1.59(\mathrm{~s}, 6 \mathrm{H}), 1.55(\mathrm{~s}, 3 \mathrm{H}), 1.27(\mathrm{dd}, J=$ 13.6, 9.2 Hz, 1H), $1.13(\mathrm{td}, J=12.5,12.0,4.4 \mathrm{~Hz}, 1 \mathrm{H}), 1.09-1.01(\mathrm{~m}, 1 \mathrm{H}), 0.97(\mathrm{~s}, 3 \mathrm{H}), 0.95-$ $0.92(\mathrm{~m}, 1 \mathrm{H}) ;{ }^{13} \mathrm{C} \mathrm{NMR}\left(150 \mathrm{MHz}, \mathrm{CDCl}_{3}\right) \delta 202.7,174.5,134.3,132.1,131.6,125.2,124.2$, $120.5,102.9,85.2,59.2,56.2,52.1,44.4,40.0,38.3,37.5,35.6,32.1,26.4,26.2,26.1,23.9,18.4$, 18.3, 18.1, 15.0; IR (thin film) 3474, 2967, 2923, 2856, 1617, $1451 \mathrm{~cm}^{-1}$; HRMS (EI) calcd for $\left[\mathrm{C}_{27} \mathrm{H}_{42} \mathrm{O}_{3}\right]: \mathrm{m} / \mathrm{z} 414.3134$, found 414.3138. Regioisomer 10: ${ }^{1} \mathrm{H} \mathrm{NMR}\left(600 \mathrm{MHz}, \mathrm{CDCl}_{3}-d\right) \delta$ $5.44(\mathrm{~s}, 1 \mathrm{H}), 5.04(\mathrm{~m}, 2 \mathrm{H}), 4.94(\mathrm{t}, J=7.1 \mathrm{~Hz}, 1 \mathrm{H}), 3.66(\mathrm{~s}, 3 \mathrm{H}), 2.69$ (d, J=17.0 Hz, 1H), 2.59 $(\mathrm{dd}, J=14.6,9.1 \mathrm{~Hz}, 1 \mathrm{H}), 2.42(\mathrm{dd}, J=15.0,5.7 \mathrm{~Hz}, 1 \mathrm{H}), 2.39(\mathrm{~d}, J=17.1 \mathrm{~Hz}, 1 \mathrm{H}), 2.35(\mathrm{dd}, J$ $=13.4,7.3 \mathrm{~Hz}, 1 \mathrm{H}), 2.10-2.04(\mathrm{~m}, 1 \mathrm{H}), 2.03-1.98(\mathrm{~m}, 1 \mathrm{H}), 1.97(\mathrm{~s}, 1 \mathrm{H}), 1.93-1.84(\mathrm{~m}, 2 \mathrm{H})$, $1.67(\mathrm{~s}, 3 \mathrm{H}), 1.62(\mathrm{~s}, 3 \mathrm{H}), 1.61(\mathrm{~s}, 3 \mathrm{H}), 1.59(\mathrm{~s}, 3 \mathrm{H}), 1.59(\mathrm{~s}, 3 \mathrm{H}), 1.53(\mathrm{~s}, 3 \mathrm{H}), 1.52$ - $1.46(\mathrm{~m}$, $1 \mathrm{H}), 1.42(\mathrm{dd}, J=13.2,10.0 \mathrm{~Hz}, 1 \mathrm{H}), 1.23(\mathrm{td}, J=12.8,12.3,4.9 \mathrm{~Hz}, 1 \mathrm{H}), 1.17(\mathrm{td}, J=13.0$, 12.6, $4.9 \mathrm{~Hz}, 1 \mathrm{H}), 0.96$ (s, 3H); ${ }^{13} \mathrm{C} \mathrm{NMR}\left(150 \mathrm{MHz}, \mathrm{CDCl}_{3}\right) \delta 197.5,180.3,134.4,131.9,131.3$, $124.9,123.9,120.6,103.6,84.8,56.3,53.8,51.8,46.6,45.5,40.3,39.9,35.9,30.6,26.1,26.0$, 
25.8, 23.6, 18.1, 18.0, 17.8, 15.3; IR (thin film) 3349, 2967, 2926, 2856, 1719, $1637 \mathrm{~cm}^{-1}$; HRMS (ESI) calcd for $\left[\mathrm{C}_{27} \mathrm{H}_{42} \mathrm{O}_{3} \mathrm{Na}\right]^{+}(\mathrm{M}+\mathrm{Na})^{+}: \mathrm{m} / \mathrm{z} 437.3026$, found 437.3028 .

Procedure for the Basic Hydrolysis of 11 (Scheme SI-2). A $100 \mathrm{~mL}$ flame-dried reaction flask was charged with vinylogous ester 11 (450 mg, $1.09 \mathrm{mmol}, 1$ equiv) and sodium hydroxide (900 $\mathrm{mg}, 22.5 \mathrm{mmol}, 21$ equiv). The reaction vessel was evacuated and backfilled with nitrogen (three times in total) followed by the addition of dioxane $(23 \mathrm{~mL})$ and deionized water $(23 \mathrm{~mL})$. The reaction mixture was heated to $80^{\circ} \mathrm{C}$ and kept at this temperature for $18 \mathrm{~h}$. The reaction mixture

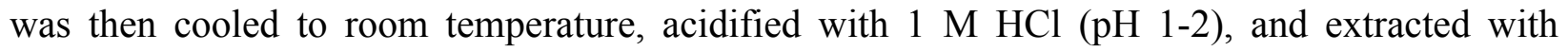
EtOAc $(3 \times 40 \mathrm{~mL})$. The combined organic washed with brine $(5 \mathrm{~mL})$, dried over $\mathrm{MgSO}_{4}$, and concentrated in vacuo. The crude residue was purified by column chromatography (20\% EtOAc in hexanes) to afford diketone 9 ( $248 \mathrm{mg}, 57 \%$ yield) as an orange oil.

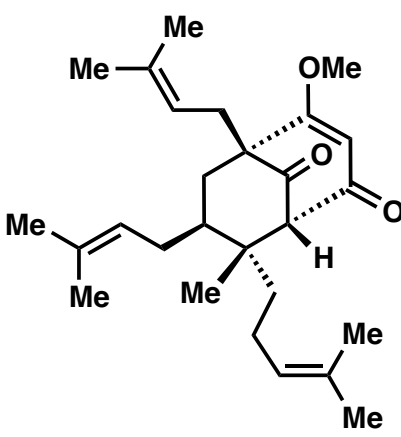

13

Bicycle 13. A $25 \mathrm{~mL}$ flame-dried flask was charged with compound 10 (50 mg, $0.121 \mathrm{mmol}, 1.0$ equiv), (Diacetoxyiodo)benzene (100 mg, $0.311 \mathrm{mmol}, 2.6$ equiv), and potassium hydroxide $(500 \mathrm{mg}, 8.93$ mmol, 74 equiv). The reaction vessel was evacuated and backfilled with nitrogen (a total of three times) followed by the addition of $\mathrm{MeOH}(5 \mathrm{~mL})$. The reaction was stirred at room temperature for $2 \mathrm{~h}$.

The resulting orange solution was concentrated in vacuo, diluted with EtOAc, washed with saturated $a q . \mathrm{NH}_{4} \mathrm{Cl}(10 \mathrm{~mL})$, and extracted with EtOAc $(3 \times 20 \mathrm{~mL})$. The combined organic layers were washed with brine, dried over $\mathrm{MgSO}_{4}$, and concentrated in vacuo. The crude residue was purified by column chromatography $\left(15 \% \mathrm{Et}_{2} \mathrm{O}\right.$ in hexanes) to afford bicycle 13 (46 mg, 92\% yield) as a yellow oil. ${ }^{1} \mathrm{H}$ NMR (600 MHz, $\left.\mathrm{CDCl}_{3}\right) \delta 5.71(\mathrm{~s}, 1 \mathrm{H}), 5.07$ $(\mathrm{t}, J=7.2 \mathrm{~Hz}, 1 \mathrm{H}), 5.01-4.89(\mathrm{~m}, 2 \mathrm{H}), 3.74(\mathrm{~s}, 3 \mathrm{H}), 3.13(\mathrm{~s}, 1 \mathrm{H}), 2.51-2.30(\mathrm{~m}, 3 \mathrm{H}), 2.13(\mathrm{~m}$, 1H), $1.93(\mathrm{dd}, J=13.9,3.8 \mathrm{~Hz}, 1 \mathrm{H}), 1.90-1.81(\mathrm{~m}, 1 \mathrm{H}), 1.69 \mathrm{z}(\mathrm{s}, 3 \mathrm{H}), 1.67(\mathrm{~s}, 6 \mathrm{H}), 1.65(\mathrm{~s}$, $3 \mathrm{H}), 1.64(\mathrm{~s}, 3 \mathrm{H}), 1.61-1.58(\mathrm{~m}, 1 \mathrm{H}), 1.56(\mathrm{~s}, 3 \mathrm{H}), 1.51(\mathrm{td}, J=13.0,4.3 \mathrm{~Hz}, 1 \mathrm{H}), 1.45-1.37$ (m, 1H), $1.26(\mathrm{~m}, 2 \mathrm{H}), 0.84(\mathrm{~s}, 3 \mathrm{H}) ;{ }^{13} \mathrm{C}$ NMR $\left(150 \mathrm{MHz}, \mathrm{CDCl}_{3}\right) \delta 207.2,194.0,177.6,133.8$, 133.3, 131.8, 124.5, 122.7, 119.6, 106.5, 70.7, 57.1, 56.9, 46.1, 41.0, 39.4, 38.7, 29.9, 27.8, 26.1, 26.0, 25.9, 22.0, 18.2, 18.1, 17.9, 17.8; IR (thin film) 2967, 2925, 2880, 1734, 1655, $1599 \mathrm{~cm}^{-1}$; HRMS (EI) calcd for $\left[\mathrm{C}_{27} \mathrm{H}_{40} \mathrm{O}_{3}\right]: \mathrm{m} / \mathrm{z} 412.2977$, found 412.2978. 


\section{Procedure for Oxidative Ring Expansion using LDA as base (Table 1).}

A $10 \mathrm{~mL}$ flame-dried flask was charged with compound 10 (50 mg, $0.121 \mathrm{mmol}, 1.0$ equiv). The reaction vessel was evacuated and backfilled with nitrogen (a total of three times) followed by the addition of THF $(5 \mathrm{~mL})$. The reaction was cooled to $-78^{\circ} \mathrm{C}$ and a freshly prepared solution of lithium diisopropylamide ( $0.52 \mathrm{M}$ in THF, $0.80 \mathrm{~mL}, 0.42 \mathrm{mmol}, 3.5$ equiv) was added dropwise. The resulting orange colored solution was stirred for 15 minutes at $-78{ }^{\circ} \mathrm{C}$ and then 30 minutes at $0 \quad{ }^{\circ} \mathrm{C}$. During this time, a separate flame-dried $25 \mathrm{~mL}$ flask was charged with [bis(trifluoroacetoxy)iodo]benzene (94 mg, $0.218 \mathrm{mmol}, 1.8$ equiv) and the flask evacuated and backfilled with nitrogen (three times in total) followed by the addition of dichloromethane ( 5 $\mathrm{mL})$. To the vessel containing PIFA was addition trimethylsilylcyanide $(0.55 \mathrm{uL}, 0.435 \mathrm{mmol}$, 3.6 equiv) at $0{ }^{\circ} \mathrm{C}$ and the mixture stirred at that temperature for 30 minutes. Both flasks were then cooled to $-78{ }^{\circ} \mathrm{C}$, and the dianion of compound $\mathbf{1 0}$ was cannula transferred into the flask containing the hypervalent iodine oxidant. The resulting yellow solution was stirred for 15 minutes at $-78{ }^{\circ} \mathrm{C}$ and then 15 minutes at $0{ }^{\circ} \mathrm{C}$. At this time, the reaction mixture was quenched with saturated $a q . \mathrm{NaHCO}_{3}(10 \mathrm{~mL})$ and extracted with EtOAc $(3 \times 20 \mathrm{~mL})$. The combined organic layers were washed with brine, dried over $\mathrm{MgSO}_{4}$, and concentrated in vacuo. The crude residue was purified by column chromatography $\left(10 \% \mathrm{Et}_{2} \mathrm{O}\right.$ in hexanes $\rightarrow 20 \%$ EtOAc in hexanes) to afford bicycle 13 (20 mg, 40\% yield) as a yellow oil and recovered starting material $10(8 \mathrm{mg}, 15 \%)$ as a colorless oil.

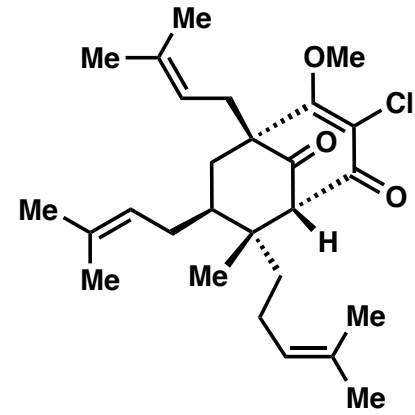

14

Chloride 14. A $25 \mathrm{~mL}$ flame-dried reaction flask was charged with compound 13 (110 mg, $0.267 \mathrm{mmol}, 1.0$ equiv). The reaction vessel was evacuated and backfilled with nitrogen (three times in total) followed by the addition of THF $(10 \mathrm{~mL})$. After cooling the reaction vessel to $-78{ }^{\circ} \mathrm{C}$, a solution of freshly prepared lithium 2,2,6,6tetramethylpiperidide $(0.50 \mathrm{M}$ in THF, $1.25 \mathrm{~mL}, 0.625 \mathrm{mmol}, 2.3$ equiv) was added dropwise resulting in a light yellow colored solution. The reaction mixture was stirred for 60 minutes at $-78{ }^{\circ} \mathrm{C}$ and then $p$-toluenesulfonyl chloride (120 mg, $0.628 \mathrm{mmol}, 2.3$ equiv) added as a solution in THF. The reaction mixture was maintained at $-78{ }^{\circ} \mathrm{C}$ for 15 minutes, warmed to $0{ }^{\circ} \mathrm{C}$ for 15 minutes, and then quenched with saturated $a q . \mathrm{NaHCO}_{3}$ solution $(5 \mathrm{~mL})$. The reaction mixture was extracted with EtOAc $(3 \times 20$ 
$\mathrm{mL}$ ) and the combined organic layers were washed with brine, dried over $\mathrm{MgSO}_{4}$, and concentrated in vacuo. The crude residue was purified by column chromatography $\left(10 \% \mathrm{CH}_{2} \mathrm{Cl}_{2}\right.$ in hexanes $\rightarrow$ 5\% ether in hexanes) affording 14 (106 mg, 89\% yield) as a yellow oil: ${ }^{1} \mathrm{H}$ NMR $\left(600 \mathrm{MHz}, \mathrm{CDCl}_{3}-d\right) \delta 5.06(\mathrm{t}, J=7.4 \mathrm{~Hz}, 1 \mathrm{H}), 4.97(\mathrm{t}, J=5.9 \mathrm{~Hz}, 1 \mathrm{H}), 4.93(\mathrm{t}, J=6.9 \mathrm{~Hz}, 1 \mathrm{H})$, $4.20(\mathrm{~s}, 3 \mathrm{H}), 3.34(\mathrm{~s}, 1 \mathrm{H}), 2.48(\mathrm{dd}, J=14.9,5.6 \mathrm{~Hz}, 1 \mathrm{H}), 2.41-2.31(\mathrm{~m}, 2 \mathrm{H}), 2.14(\mathrm{dd}, J=$ 13.6, $5.8 \mathrm{~Hz}, 1 \mathrm{H}), 2.02(\mathrm{dd}, J=14.0,4.1 \mathrm{~Hz}, 1 \mathrm{H}), 1.85$ (tt, $J=12.8,5.3 \mathrm{~Hz}, 1 \mathrm{H}), 1.70$ (s, 3H), $1.68-1.64(\mathrm{~m}, 12 \mathrm{H}), 1.64-1.59(\mathrm{~m}, 1 \mathrm{H}), 1.56(\mathrm{~s}, 3 \mathrm{H}), 1.51(\mathrm{dd}, J=12.8,4.5 \mathrm{~Hz}, 1 \mathrm{H}), 1.42$ (ddd, $J=13.8,11.7,3.4 \mathrm{~Hz}, 1 \mathrm{H}), 1.22$ (tt, $J=13.1,5.9 \mathrm{~Hz}, 1 \mathrm{H}), 1.01-0.91(\mathrm{~m}, 1 \mathrm{H}), 0.85$ (s, $3 \mathrm{H}) ;{ }^{13} \mathrm{C} \mathrm{NMR}\left(150 \mathrm{MHz}, \mathrm{CDCl}_{3}\right) \delta 205.2,187.9,172.3,134.2,133.7,132.0,124.2,122.4$, $119.4,115.7,70.6,62.8,60.2,46.9,41.1,39.5,38.6,30.7,27.7,26.0,26.0,25.9,21.9,18.2,18.2$, 17.9, 17.8; IR (thin film) 2967, 2925, 2878, 1735, 1673, $1579 \mathrm{~cm}^{-1}$; HRMS (EI) calcd for $\left[\mathrm{C}_{27} \mathrm{H}_{39} \mathrm{ClO}_{3}\right]: \mathrm{m} / \mathrm{z} 446.2588$, found 446.2587 .

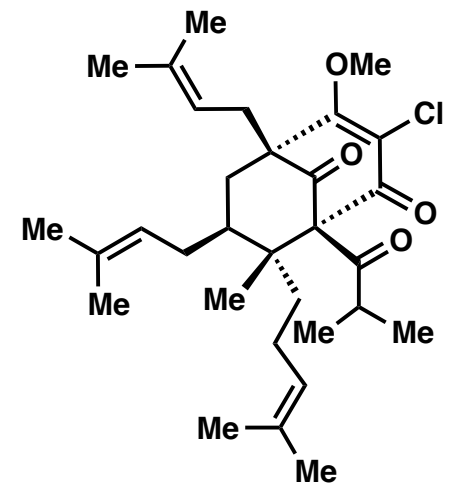

15

Chloride 15. Two $20 \mathrm{~mL}$ flame-dried reaction tubes were charged with compound 14 ( 2 x $46 \mathrm{mg}, 0.206 \mathrm{mmol}, 1.0$ equiv). The reaction vessels were evacuated and backfilled with nitrogen (three times in total) followed by the addition of THF $(1 \mathrm{~mL})$. The reaction mixtures were cooled to $-78{ }^{\circ} \mathrm{C}$ and a freshly prepared solution of lithium 2,2,6,6-tetramethylpiperidide (0.50 M in THF, $0.62 \mathrm{~mL}, 0.31 \mathrm{mmol}$, 3.2 equiv) was added dropwise to each vessel resulting in a light brown colored solution. The reaction mixtures were stirred for 10 minutes at $-78^{\circ} \mathrm{C}$, warmed to $0{ }^{\circ} \mathrm{C}$ and stirred 5 minutes, and then recooled to $-78{ }^{\circ} \mathrm{C}$. Isobutyryl cyanide $(50 \mu \mathrm{L}, 0.49 \mathrm{mmol}, 5$ equiv) was added dropwise to both vessels at $-78{ }^{\circ} \mathrm{C}$. The reaction mixtures were slowly warmed to $-35{ }^{\circ} \mathrm{C}$ over the course of 30 minutes at which point they were quenched with saturated $a q . \mathrm{NaHCO}_{3}$ solution $(5 \mathrm{~mL})$. The two reaction mixtures were combined and extracted with EtOAc $(3 \times 20 \mathrm{~mL})$. The combined organic layers were washed with brine, dried over $\mathrm{MgSO}_{4}$, and concentrated in vacuo. The crude residue was purified by column chromatography (2\% ether in hexanes) to afford the chloride product 15 (75 mg, 70\% yield) as a yellow oil: ${ }^{1} \mathrm{H} \mathrm{NMR}\left(400 \mathrm{MHz}, \mathrm{CDCl}_{3}-d\right) \delta 5.02(\mathrm{t}, J=7.1 \mathrm{~Hz}, 1 \mathrm{H})$, $4.99-4.89(\mathrm{~m}, 2 \mathrm{H}), 4.25(\mathrm{~s}, 3 \mathrm{H}), 2.52(\mathrm{dd}, J=14.6,5.4 \mathrm{~Hz}, 1 \mathrm{H}), 2.42$ (dd, $J=14.6,7.9 \mathrm{~Hz}$, $1 \mathrm{H}), 2.16-2.03(\mathrm{~m}, 3 \mathrm{H}), 2.03-1.96(\mathrm{~m}, 1 \mathrm{H}), 1.94(\mathrm{dd}, J=13.6,4.0 \mathrm{~Hz}, 1 \mathrm{H}), 1.88-1.81(\mathrm{~m}$, 2H), $1.81-1.73(\mathrm{~m}, 1 \mathrm{H}), 1.70(\mathrm{~s}, 3 \mathrm{H}), 1.68(\mathrm{~m}, 6 \mathrm{H}), 1.64(\mathrm{~s}, 3 \mathrm{H}), 1.59(\mathrm{~s}, 3 \mathrm{H}), 1.56(\mathrm{~s}, 3 \mathrm{H}), 1.47$ 
(t, $J=5.4 \mathrm{~Hz}, 1 \mathrm{H}), 1.45-1.39(\mathrm{~m}, 1 \mathrm{H}), 1.13(\mathrm{~d}, J=6.5 \mathrm{~Hz}, 3 \mathrm{H}), 1.06(\mathrm{~d}, J=6.5 \mathrm{~Hz}, 3 \mathrm{H}), 1.02$ $(\mathrm{d}, J=2.1 \mathrm{~Hz}, 3 \mathrm{H}) ;{ }^{13} \mathrm{C} \mathrm{NMR}\left(100 \mathrm{MHz}, \mathrm{CDCl}_{3}\right) \delta 208.0,205.2,187.2,172.0,134.7,133.9$, 131.5, 124.5, 122.3, 119.1, 116.1, 84.4, 63.0, 60.6, 50.2, 43.0, 39.6, 36.6, 30.6, 27.4, 26.1, 26.0, 25.9, 25.0, 21.6, 20.6, 18.3, 18.2, 17.8, 13.9; IR (thin film) 2924, 2869, 2852, 1734, 1663, 1582 $\mathrm{cm}-1$; HRMS (EI) calcd for $\left[\mathrm{C}_{31} \mathrm{H}_{45} \mathrm{ClO}_{4}\right]$ : $\mathrm{m} / \mathrm{z} 516.3006$, found 516.2999.

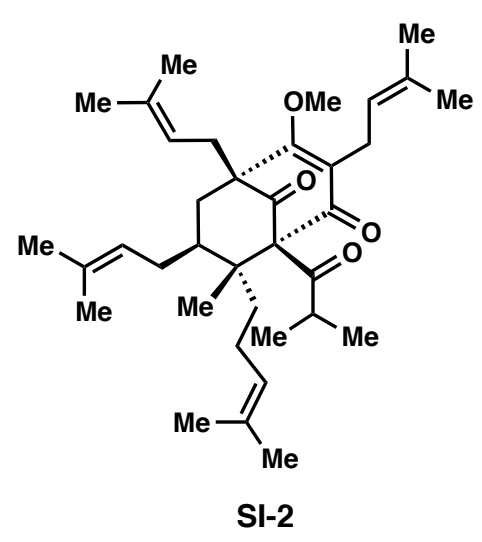

$\boldsymbol{O}$-methylhyperforin (SI-2). A $10 \mathrm{~mL}$ flame-dried flask was charged with compound 15 (50 mg, $0.10 \mathrm{mmol}, 1.0$ equiv). The reaction vessel was evacuated and backfilled with nitrogen (three times in total) followed by the addition of THF $(5 \mathrm{~mL})$. The solution was cooled to $0{ }^{\circ} \mathrm{C}$ and $i$ - $\mathrm{PrMgCl} \cdot \mathrm{LiCl}$ solution (1.3 $\mathrm{M}$ in $\mathrm{Et}_{2} \mathrm{O}, 0.26 \mathrm{~mL}, 0.34 \mathrm{mmol}, 3.4$ equiv) was added dropwise. After 15 minutes at $0{ }^{\circ} \mathrm{C}$, the reaction mixture was warmed to room temperature and stirred for 75 minutes. The reaction vessel was then cooled to $-78{ }^{\circ} \mathrm{C}$, and freshly prepared lithium diisopropylamide $(0.52 \mathrm{M}$ in THF, $0.73 \mathrm{~mL}$, $0.38 \mathrm{mmol}, 3.8$ equiv) was added dropwise. After stirring for 20 minutes at this temperature, 2thienyl(cyano)copperlithium ( $0.25 \mathrm{M}$ in THF, $2.7 \mathrm{~mL}, 0.68 \mathrm{mmol}, 7$ equiv) was added dropwise. The reaction mixture was stirred for 5 minutes at $-78^{\circ} \mathrm{C}$ and then warmed to $-40{ }^{\circ} \mathrm{C}$ and stirred an additional 30 minutes. The mixture was then re-cooled to $-78^{\circ} \mathrm{C}$ and freshly distilled prenyl bromide (190 $\mu \mathrm{L}, 1.7 \mathrm{mmol}, 17$ equiv) was added. The reaction mixture was warmed to $-30{ }^{\circ} \mathrm{C}$ over the course of 90 minutes and then quenched with saturated $a q . \mathrm{NH}_{4} \mathrm{Cl}$ and extracted with EtOAc $(3 \times 20 \mathrm{~mL})$. The combined organic layers were washed with brine, dried over $\mathrm{MgSO}_{4}$, and concentrated in vacuo. The crude residue was purified by column chromatography $\left(2 \% \mathrm{Et}_{2} \mathrm{O}\right.$ in hexanes) affording $O$-methylhyperforin (39 mg, 73\% yield) as a colorless oil: ${ }^{1} \mathrm{H}$ NMR (400 $\left.\mathrm{MHz}, \mathrm{CDCl}_{3}-d\right) \delta 5.09-5.02(\mathrm{~m}, 2 \mathrm{H}), 5.02-4.97(\mathrm{~m}, 1 \mathrm{H}), 4.97-4.92(\mathrm{~m}, 1 \mathrm{H}), 3.92(\mathrm{~s}, 3 \mathrm{H})$, $3.18(\mathrm{~d}, J=6.5 \mathrm{~Hz}, 2 \mathrm{H}), 2.50$ (dd, $J=14.8,6.1 \mathrm{~Hz}, 1 \mathrm{H}), 2.40$ (dd, $J=14.7,7.4 \mathrm{~Hz}, 1 \mathrm{H}), 2.09$ (t, $J=14.1 \mathrm{~Hz}, 2 \mathrm{H}), 1.98$ (septet, $J=6.4 \mathrm{~Hz}, 1 \mathrm{H}), 1.93-1.84(\mathrm{~m}, 3 \mathrm{H}), 1.79-1.71(\mathrm{~m}, 1 \mathrm{H}), 1.69-$ $1.65(\mathrm{~m}, 15 \mathrm{H}), 1.64(\mathrm{~s}, 3 \mathrm{H}), 1.63-1.60(\mathrm{~m}, 1 \mathrm{H}), 1.59(\mathrm{~s}, 3 \mathrm{H}), 1.56(\mathrm{~s}, 3 \mathrm{H}), 1.46-1.40(\mathrm{~m}, 1 \mathrm{H})$, $1.40-1.35(\mathrm{~m}, 1 \mathrm{H}), 1.11(\mathrm{~d}, J=6.5 \mathrm{~Hz}, 3 \mathrm{H}), 1.02(\mathrm{~d}, J=6.5 \mathrm{~Hz}, 3 \mathrm{H}), 0.99(\mathrm{~s}, 3 \mathrm{H}) ;{ }^{13} \mathrm{C} \mathrm{NMR}$ $\left(100 \mathrm{MHz}, \mathrm{CDCl}_{3}\right) \delta$ 209.3, 207.3, 194.1, 174.1, 134.0, 133.5, 133.2, 131.2, 127.7, 125.0, 122.7, $121.9,119.9,84.3,62.6,58.9,49.4,43.4,42.8,39.1,36.7,30.3,27.3,26.1,26.0,25.9,25.8,25.1$, 
23.7, 21.5, 20.6, 18.3, 18.14, 18.13, 17.9, 13.8; IR (thin film) 2967, 2926, 2873, 1730, 1720, $1646 \mathrm{~cm}^{-1}$; HRMS (ESI) calcd for $\left[\mathrm{C}_{36} \mathrm{H}_{54} \mathrm{O}_{4} \mathrm{Na}\right]^{+}(\mathrm{M}+\mathrm{Na})^{+}: \mathrm{m} / \mathrm{z} 573.3914$ found 573.3913.

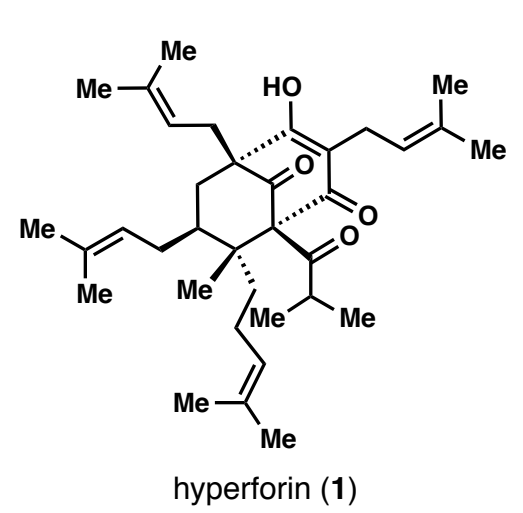

Hyperforin (1). [Note: The following procedure was conducted in the dark. Solvents used were degassed with argon for 10 minutes prior to use]. A $10 \mathrm{~mL}$ flame-dried reaction tube was charged with compound $O$-methylhyperforin $(53 \mathrm{mg}, 0.096$ mmol, 1 equiv) and dry lithium chloride (40 mg, $0.95 \mathrm{mmol}, 10$ equiv). The reaction vessel was evacuated and backfilled with nitrogen three times followed by the addition of DMSO $(2 \mathrm{~mL})$. The reaction mixture was heated to $120{ }^{\circ} \mathrm{C}$ and kept at this temperature for 30 minutes. The reaction mixture was then cooled to room temperature, diluted with $\mathrm{H}_{2} \mathrm{O}$, and extracted with 1:1 hexane:EtOAc $(3 \times 20 \mathrm{~mL})$. The combined organic layers extracts were washed with $\mathrm{H}_{2} \mathrm{O}(3 \times 5 \mathrm{~mL})$, washed with brine $(5 \mathrm{~mL})$, dried over $\mathrm{Na}_{2} \mathrm{SO}_{4}$, and concentrated in vacuo to afford a yellow oil. The crude residue was purified by column chromatography ( $2 \% \rightarrow 5 \%$ EtOAc in hexanes) to afford hyperforin ( $29 \mathrm{mg}, 56 \%$ yield) as an oil: ${ }^{1} \mathrm{H}$ NMR (600 MHz, MeOD- $\left.d_{4}\right) \delta 5.12(\mathrm{t}, J=6.4 \mathrm{~Hz}, 1 \mathrm{H}), 5.04-4.96(\mathrm{~m}, 3 \mathrm{H}), 3.16(\mathrm{dd}, J=$ 14.8, 7.2 Hz, 1H), $3.10(\mathrm{dd}, J=14.8,6.9 \mathrm{~Hz}, 1 \mathrm{H}), 2.52(\mathrm{dd}, J=14.9,6.8 \mathrm{~Hz}, 1 \mathrm{H}), 2.43(\mathrm{dd}, J=$ 14.6, $7.1 \mathrm{~Hz}, 1 \mathrm{H}), 2.14-2.12(\mathrm{~m}, 1 \mathrm{H}), 2.11-2.04(\mathrm{~m}, 1 \mathrm{H}), 2.04-1.97(\mathrm{~m}, 1 \mathrm{H}), 1.97-1.89(\mathrm{~m}$, 2H), $1.80-1.74(\mathrm{~m}, 4 \mathrm{H}), 1.73(\mathrm{~s}, 3 \mathrm{H}), 1.71(\mathrm{~s}, 6 \mathrm{H}), 1.68(\mathrm{~s}, 3 \mathrm{H}), 1.67(\mathrm{~s}, 3 \mathrm{H}), 1.65(\mathrm{~s}, 3 \mathrm{H}), 1.62$ (s, 3H), $1.60(\mathrm{~s}, 3 \mathrm{H}), 1.41$ (t, $J=12.7 \mathrm{~Hz}, 1 \mathrm{H}), 1.11(\mathrm{~d}, J=6.5 \mathrm{~Hz}, 3 \mathrm{H}), 1.06(\mathrm{~d}, J=6.5 \mathrm{~Hz}, 3 \mathrm{H})$, 1.00 (s, 3H); ${ }^{13} \mathrm{C}$ NMR (150 MHz, MeOD- $\left.d_{4}\right) \delta$ 212.2, 209.3, 134.9, 134.5, 133.8, 132.1, 126.4, $124.1,123.0,122.3,121.3,49.9,43.4,43.3,41.1,38.3,31.0,29.0,26.4,26.3,26.3,26.2,25.8$, 22.9, 22.3, 21.4, 18.5, 18.4, 18.4, 18.1, 15.6; IR (thin film) 3314, 2968, 2927, 2874, 1723, 1602 $\mathrm{cm}^{-1}$; HRMS (ESI) calcd for $\left[\mathrm{C}_{35} \mathrm{H}_{51} \mathrm{O}_{4}\right]^{-}(\mathrm{M}-\mathrm{H})^{-}: \mathrm{m} / \mathrm{z} 535.3793$ found 535.3783. 
${ }^{1} \mathrm{H}$ and ${ }^{13} \mathrm{C}$ NMR comparison of natural and synthetic hyperforin

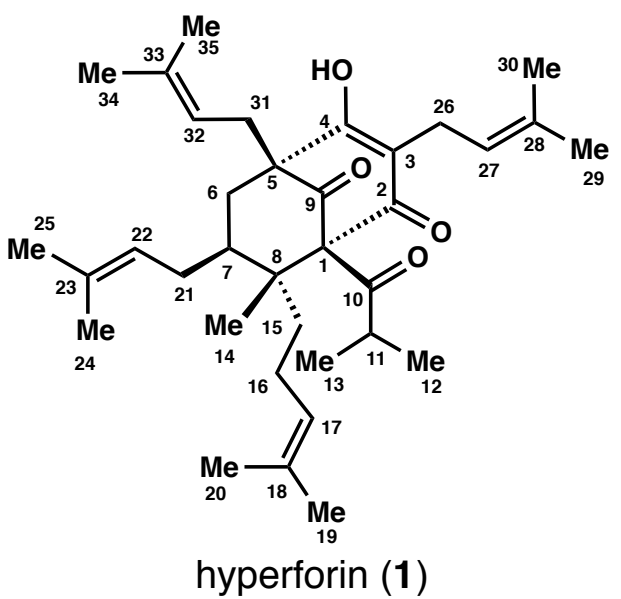

\section{References}

1. Cao, X.; Wang, Q.; Li, Y.; Bai, G.; Ren, H.; Xu, C.; Ito, Y. J. Chromatogr. B. 2011, 879, 480-488.

2. Shimizu, Y.; Shi, S.-L.; Usuda, H.; Kanai, M.; Shibasaki, M. Tetrahedron 2010, 66, 6569- 6584.

3. Sparling, A. B.; Moebius, D. C.; Shair, M. D. J. Am. Chem. Soc. 2013, 135, 644-647.

4. Uwamori, M.; Nakada, M. Tetrahedron Lett. 2013, 54, 2022-2025.

5. Bellavance, G.; Barriault, L. Angew. Chem. Int. Ed. 2014, 53, 6701. 


\begin{tabular}{|c|c|c|c|c|c|c|}
\hline $\mathrm{C}$ & $600 \mathrm{MHz}^{1}$ & $500 \mathrm{MHz}^{2}$ & $500 \mathrm{MHz}^{3}$ & $600 \mathrm{MHz}^{4}$ & $500 \mathrm{MHz}^{5}$ & $600 \mathrm{MHz}$ (this work) \\
\hline 27 & $5.18(\mathrm{tt}, J=7.2,1.2 \mathrm{~Hz}, 1 \mathrm{H})$ & $5.15-5.11(\mathrm{~m}, 1 \mathrm{H})$ & $5.12(\mathrm{t}, J=7.0 \mathrm{~Hz}, 1 \mathrm{H})$ & $5.10-5.00(\mathrm{~m}, 1 \mathrm{H})$ & $\begin{array}{r}5.09(\mathrm{tt}, J=7.1,1.3 \\
1 \mathrm{H})\end{array}$ & $5.12(\mathrm{t}, J=6.4 \mathrm{~Hz}, 1 \mathrm{H})$ \\
\hline 22 & $5.11(\mathrm{tt}, J=7.2,1.2 \mathrm{~Hz}, 1 \mathrm{H})$ & $5.07-4.97(\mathrm{~m}, 3 \mathrm{H})$ & $5.04-4.95(\mathrm{~m}, 3 \mathrm{H})$ & $5.00-4.88(\mathrm{~m}, 3 \mathrm{H})$ & $5.03-4.94(\mathrm{~m}, 3 \mathrm{H})$ & $5.04-4.96(\mathrm{~m}, 3 \mathrm{H})$, \\
\hline 32 & $4.76(\mathrm{tq}, J=7.2,1.2 \mathrm{~Hz}, 1 \mathrm{H})$ & & & & & \\
\hline 17 & $4.76(\mathrm{tq}, J=7.2,1.2 \mathrm{~Hz}, 1 \mathrm{H})$ & & & & & \\
\hline $26 \mathrm{a}$ & 3.20 (septet, $J=7.2 \mathrm{~Hz}, 2 \mathrm{H}$ ) & $3.17(\mathrm{dd}, J=14.7,7.0 \mathrm{~Hz}, 1 \mathrm{H})$ & $3.12(\mathrm{dd}, J=14.6,7.2 \mathrm{~Hz}, 1 \mathrm{H})$ & $\begin{array}{r}3.10(\mathrm{dd}, J=14.4,7.2 \mathrm{~Hz} \\
1 \mathrm{H})\end{array}$ & $\begin{array}{r}3.13(\mathrm{dd}, J=14.9 \\
6.9 \mathrm{~Hz}, 1 \mathrm{H}) \\
\end{array}$ & $3.16(\mathrm{dd}, J=14.8,7.2 \mathrm{~Hz}, 1 \mathrm{H})$ \\
\hline $26 \mathrm{~b}$ & & $3.11(\mathrm{dd}, J=14.7,6.7 \mathrm{~Hz}, 1 \mathrm{H})$ & $3.07(\mathrm{dd}, J=14.7,7.1 \mathrm{~Hz}, 1 \mathrm{H})$ & $\begin{array}{r}3.05(\mathrm{dd}, J=14.4,7.2 \mathrm{~Hz} \\
1 \mathrm{H})\end{array}$ & $\begin{array}{r}3.07(\mathrm{dd}, J=14.9, \\
6.9 \mathrm{~Hz}, 1 \mathrm{H}) \\
\end{array}$ & $3.10(\mathrm{dd}, J=14.8,6.9 \mathrm{~Hz}, 1 \mathrm{H})$ \\
\hline $31 \mathrm{a}$ & $2.49(\mathrm{dd}, J=7.2,4.8 \mathrm{~Hz}, 2 \mathrm{H})$ & $2.54(\mathrm{dd}, J=14.1,6.7 \mathrm{~Hz}, 1 \mathrm{H})$ & $2.49(\mathrm{dd}, J=14.4,6.9 \mathrm{~Hz}, 1 \mathrm{H})$ & $\begin{array}{r}2.47(\mathrm{dd}, J=14.4,6.6 \mathrm{~Hz} \\
1 \mathrm{H})\end{array}$ & $\begin{array}{r}2.50(\mathrm{dd}, J=14.6 \\
6.9 \mathrm{~Hz}, 1 \mathrm{H}) \\
\end{array}$ & $2.52(\mathrm{dd}, J=14.9,6.8 \mathrm{~Hz}, 1 \mathrm{H})$ \\
\hline $31 b$ & & $2.44(\mathrm{dd}, \mathrm{J}=14.1,7.0 \mathrm{~Hz}, 1 \mathrm{H})$ & $2.40(\mathrm{dd}, \mathrm{J}=14.6,6.8 \mathrm{~Hz}, 1 \mathrm{H})$ & $\begin{array}{r}2.37(\mathrm{dd}, J=14.4,6.6 \mathrm{~Hz} \\
1 \mathrm{H})\end{array}$ & $\begin{array}{r}2.41(\mathrm{dd}, J=14.6, \\
7.1 \mathrm{~Hz}, 1 \mathrm{H}) \\
\end{array}$ & $2.43(\mathrm{dd}, J=14.6,7.1 \mathrm{~Hz}, 1 \mathrm{H})$ \\
\hline 11 & $2.11(\mathrm{~m}, 1 \mathrm{H})$ & $2.19-1.90(\mathrm{~m}, 5 \mathrm{H})$ & 2.14 (septet, $J=6.5 \mathrm{~Hz}, 1 \mathrm{H})$ & $2.20-2.11(\mathrm{~m}, 2 \mathrm{H})$ & $2.11-2.02(\mathrm{~m}, 2 \mathrm{H})$ & $2.14-2.12(\mathrm{~m}, 1 \mathrm{H})$ \\
\hline $16 \mathrm{a}$ & $2.02(\mathrm{~m}, 2 \mathrm{H})$ & & $2.10-2.02(\mathrm{~m}, 1 \mathrm{H})$ & & & $2.11-2.04(\mathrm{~m}, 1 \mathrm{H})$ \\
\hline $6 \mathrm{a}$ & & & $2.02-1.87(\mathrm{~m}, 3 \mathrm{H})$ & $2.01-1.91(\mathrm{~m}, 1 \mathrm{H})$ & $2.01-1.86(\mathrm{~m}, 3 \mathrm{H})$ & $2.04-1.97(\mathrm{~m}, 1 \mathrm{H})$ \\
\hline $21 \mathrm{a}$ & $2.02(\mathrm{~m}, 1 \mathrm{H})$ & & & $\begin{array}{r}1.97(\mathrm{dd}, J=13.2,4.8 \mathrm{~Hz} \\
1 \mathrm{H}) \\
\end{array}$ & & $1.97-1.89(\mathrm{~m}, 2 \mathrm{H})$ \\
\hline $21 b$ & $1.92(\mathrm{~m}, 2 \mathrm{H})$ & & & $\begin{array}{r}1.88(\mathrm{dd}, \mathrm{J}=13.2,4.2 \mathrm{~Hz} \\
1 \mathrm{H})\end{array}$ & & \\
\hline 7 & $1.80(\mathrm{~m}, 2 \mathrm{H})$ & $1.79-1.66(\mathrm{~m}, 4 \mathrm{H})$ & $1.78-1.72(\mathrm{~m}, 3 \mathrm{H})$ & $1.75-1.62(\mathrm{~m}, 4 \mathrm{H})$ & $1.77-1.70(\mathrm{~m}, 3 \mathrm{H})$ & $1.80-1.74(\mathrm{~m}, 4 \mathrm{H})$ \\
\hline $15 \mathrm{a}$ & & & & & & \\
\hline $16 \mathrm{~b}$ & $1.80(\mathrm{~m}, 1 \mathrm{H})$ & & & & & \\
\hline $15 b$ & $1.75(\mathrm{~m}, 1 \mathrm{H})$ & & $1.66-1.63(\mathrm{~m}, 1 \mathrm{H})$ & & $1.68-1.63(\mathrm{~m}, 1 \mathrm{H})$ & \\
\hline $6 \mathrm{~b}$ & $1.27(\mathrm{~m}, 1 \mathrm{H})$ & $1.47-1.38(\mathrm{~m}, 1 \mathrm{H})$ & $\begin{array}{r}1.37(\mathrm{dd}, \mathrm{J}=13.3,12.2 \mathrm{~Hz} \\
1 \mathrm{H})\end{array}$ & $1.42-1.34(\mathrm{~m}, 1 \mathrm{H})$ & $\begin{array}{r}1.39(\mathrm{dd}, J=13.3, \\
12.2,1 \mathrm{H}) \\
\end{array}$ & $1.41(\mathrm{t}, J=12.7 \mathrm{~Hz}, 1 \mathrm{H})$ \\
\hline 30 & $1.70(\mathrm{~s}, 3 \mathrm{H})$ & $1.74(\mathrm{~s}, 3 \mathrm{H})$ & $1.71(\mathrm{~s}, 3 \mathrm{H})$ & $1.69(\mathrm{~s}, 3 \mathrm{H})$ & $1.70(\mathrm{~s}, 3 \mathrm{H})$ & $1.73(\mathrm{~s}, 3 \mathrm{H})$ \\
\hline 19 & $1.64(\mathrm{~s}, 3 \mathrm{H})$ & $1.72(\mathrm{~s}, 6 \mathrm{H})$ & $1.68(\mathrm{~s}, 6 \mathrm{H})$ & $1.67(\mathrm{~s}, 6 \mathrm{H})$ & $1.68(\mathrm{~s}, 6 \mathrm{H})$ & $1.71(\mathrm{~s}, 6 \mathrm{H})$ \\
\hline 34 & $1.60(\mathrm{~s}, 6 \mathrm{H})$ & & & & & \\
\hline 35 & & $1.69(\mathrm{~s}, 3 \mathrm{H})$ & $1.66(\mathrm{~s}, 3 \mathrm{H})$ & $1.64(\mathrm{~s}, 3 \mathrm{H})$ & $1.65(\mathrm{~s}, 3 \mathrm{H})$ & $1.68(\mathrm{~s}, 3 \mathrm{H})$ \\
\hline 24 & $1.50(\mathrm{~s}, 3 \mathrm{H})$ & $1.68(\mathrm{~s}, 3 \mathrm{H})$ & $1.64(\mathrm{~s}, 3 \mathrm{H})$ & $1.62(\mathrm{~s}, 3 \mathrm{H})$ & $\begin{array}{r}1.64(\mathrm{~d}, J=0.8 \mathrm{~Hz}, \\
3 \mathrm{H})\end{array}$ & $1.67(\mathrm{~s}, 3 \mathrm{H})$ \\
\hline 29 & $1.50(\mathrm{~s}, 3 \mathrm{H})$ & $1.66(\mathrm{~s}, 3 \mathrm{H})$ & $1.63(\mathrm{~s}, 3 \mathrm{H})$ & $1.62(\mathrm{~s}, 3 \mathrm{H})$ & $\begin{array}{r}1.62(\mathrm{~d}, \mathrm{~J}=0.8 \mathrm{~Hz}, \\
3 \mathrm{H})\end{array}$ & $1.65(\mathrm{~s}, 3 \mathrm{H})$ \\
\hline 25 & $1.50(\mathrm{~s}, 3 \mathrm{H})$ & $1.62(\mathrm{~s}, 3 \mathrm{H})$ & $1.59(\mathrm{~s}, 3 \mathrm{H})$ & $1.58(\mathrm{~s}, 3 \mathrm{H})$ & $1.59(\mathrm{~s}, 3 \mathrm{H})$ & $1.62(\mathrm{~s}, 3 \mathrm{H})$ \\
\hline 20 & $1.47(\mathrm{~s}, 3 \mathrm{H})$ & $1.61(\mathrm{~s}, 3 \mathrm{H})$ & $1.58(\mathrm{~s}, 3 \mathrm{H})$ & $1.57(\mathrm{~s}, 3 \mathrm{H})$ & $1.58(\mathrm{~s}, 3 \mathrm{H})$ & $1.60(\mathrm{~s}, 3 \mathrm{H})$ \\
\hline 12 & $1.15(\mathrm{dd}, 6 \mathrm{H})$ & $1.12(\mathrm{~d}, J=6.4 \mathrm{~Hz}, 3 \mathrm{H})$ & $1.09(\mathrm{~d}, J=6.5 \mathrm{~Hz}, 3 \mathrm{H})$ & $1.08(\mathrm{~d}, J=6.6 \mathrm{~Hz}, 3 \mathrm{H})$ & $\begin{array}{r}1.09(\mathrm{~d}, J=6.4 \mathrm{~Hz}, \\
3 \mathrm{H})\end{array}$ & $1.11(\mathrm{~d}, J=6.5 \mathrm{~Hz}, 3 \mathrm{H})$ \\
\hline 13 & & $1.06(\mathrm{~d}, J=6.4 \mathrm{~Hz}, 3 \mathrm{H})$ & $1.04(\mathrm{~d}, J=6.5 \mathrm{~Hz}, 3 \mathrm{H})$ & $1.03(\mathrm{~d}, J=6.6 \mathrm{~Hz}, 3 \mathrm{H})$ & $\begin{array}{r}1.03(\mathrm{~d}, J=6.6 \mathrm{~Hz}, \\
3 \mathrm{H})\end{array}$ & $1.06(\mathrm{~d}, J=6.5 \mathrm{~Hz}, 3 \mathrm{H})$ \\
\hline 14 & $0.98(\mathrm{~s}, 3 \mathrm{H})$ & $1.01(\mathrm{~s}, 3 \mathrm{H})$ & $0.97(\mathrm{~s}, 3 \mathrm{H})$ & $0.96(\mathrm{~s}, 3 \mathrm{H})$ & $0.97(\mathrm{~s}, 3 \mathrm{H})$ & $1.00(\mathrm{~s}, 3 \mathrm{H})$ \\
\hline
\end{tabular}




\begin{tabular}{|c|c|c|c|c|c|c|}
\hline${ }^{13} \mathrm{C}$ & $150 \mathrm{MHz}^{1}$ & $125 \mathrm{MHz}^{2}$ & $125 \mathrm{MHz}^{3}$ & $150 \mathrm{MHz}^{4}$ & $125 \mathrm{MHz}^{5}$ & $\begin{array}{r}150 \\
\mathrm{MHz} \\
\text { (this } \\
\text { work) } \\
\end{array}$ \\
\hline 10 & 209.64 & na & 211.7 & na & 211.8 & 212.2 \\
\hline 9 & 208.35 & na & 208.8 & na & 208.9 & 209.3 \\
\hline 2 & 183.18 & na & na & & na & na \\
\hline 4 & 181.59 & na & na & na & na & na \\
\hline 33 & 133.36 & 135.44 & 134.6 & 134.1 & 134.7 & 134.9 \\
\hline 23 & 133.19 & 134.04 & 134.2 & 134.0 & 134.3 & 134.5 \\
\hline 28 & 132.93 & 132.63 & 133.5 & 132.4 & 133.6 & 133.8 \\
\hline 18 & 131.61 & na & 131.8 & 131.6 & 131.9 & 132.1 \\
\hline 17 & 126.61 & 126.98 & 126.0 & 126.4 & 126.1 & 126.4 \\
\hline 22 & 122.71 & 124.73 & 123.8 & 124.1 & 123.9 & 124.1 \\
\hline 27 & 122.31 & 123.66 & 122.6 & 123.6 & 122.6 & 123.0 \\
\hline 3 & 121.21 & 122.82 & 122.1 & 121.7 & 122.1 & 122.3 \\
\hline 32 & 120.25 & 121.90 & 120.9 & 121.6 & 120.9 & 121.3 \\
\hline 1 & 82.42 & na & 82.6 & na & na & na \\
\hline 5 & 58.27 & na & 60.7 & na & na & na \\
\hline 8 & 47.81 & na & 49.5 & na & 49.5 & 49.9 \\
\hline 11 & 42.57 & 43.94 & 43.1 & 43.3 & 43.1 & 43.4 \\
\hline 7 & 41.57 & 43.68 & 43.0 & 42.8 & 43.0 & 43.3 \\
\hline 6 & 40.27 & 41.68 & 40.8 & 40.7 & 40.8 & 41.1 \\
\hline 15 & 37.68 & 38.81 & 37.9 & 38.0 & 37.9 & 38.3 \\
\hline 31 & 30.03 & 31.59 & 30.7 & 30.9 & 30.7 & 31.0 \\
\hline 21 & 27.66 & 29.52 & 28.6 & 28.7 & 28.7 & 29.0 \\
\hline 34 & 25.01 & 27.02 & 26.2 & 26.2 & 26.2 & 26.4 \\
\hline 29 & 24.99 & 26.90 & 26.1 & 26.1 & 26.1 & 26.3 \\
\hline 24 & 24.90 & 26.83 & 26.0 & 26.0 & 26.0 & 26.3 \\
\hline 19 & 24.88 & 26.74 & 25.9 & 25.9 & 25.9 & 26.2 \\
\hline 16 & 24.00 & 26.33 & 25.4 & 25.6 & 25.5 & 25.8 \\
\hline 26 & 22.40 & 23.43 & 22.5 & 22.9 & 22.6 & 22.9 \\
\hline 12 & 20.44 & 22.86 & 22.0 & 22.2 & 22.0 & 22.3 \\
\hline 13 & 19.36 & 22.01 & 21.2 & 21.2 & 21.2 & 21.4 \\
\hline 35 & 18.14 & 19.10 & 18.3 & 18.3 & 18.3 & 18.5 \\
\hline 25 & 18.10 & 19.01 & 18.2 & 18.2 & 18.2 & 18.4 \\
\hline 20 & 18.01 & 18.94 & 18.1 & 18.1 & 18.1 & 18.4 \\
\hline 30 & 17.92 & 18.70 & 17.9 & 17.9 & 17.9 & 18.1 \\
\hline 14 & 15.80 & 16.13 & 15.3 & 15.3 & 15.3 & 15.6 \\
\hline
\end{tabular}




\section{X-ray Crystallography of 11}

A colorless plate $0.060 \times 0.040 \times 0.010 \mathrm{~mm}$ in size was mounted on a Cryoloop with Paratone oil. Data were collected in a nitrogen gas stream at 100(2) K using phi and omega scans. Crystalto-detector distance was $60 \mathrm{~mm}$ and exposure time was 20 seconds per frame using a scan width of $2.0^{\circ}$. Data collection was $99.8 \%$ complete to $67.000^{\circ}$ in $\theta$. A total of 36801 reflections were collected covering the indices, $-7<=h<=8,-24<=k<=24,-18<=l<=20.4502$ reflections were found to be symmetry independent, with an $\mathrm{R}_{\text {int }}$ of 0.0657 . Indexing and unit cell refinement indicated a primitive, monoclinic lattice. The space group was found to be P 21/n (No. 14). The data were integrated using the Bruker SAINT software program and scaled using the SADABS software program. Solution by iterative methods (SHELXT) produced a complete heavy-atom phasing model consistent with the proposed structure. All non-hydrogen atoms were refined anisotropically by full-matrix least-squares (SHELXL-2014). All hydrogen atoms were placed using a riding model. Their positions were constrained relative to their parent atom using the appropriate HFIX command in SHELXL-2014. 
Crystal data and structure refinement for compound $\mathbf{1 1}$

Empirical formula

Formula weight

Temperature

Wavelength

Crystal system

Space group

Unit cell dimensions

Volume

$\mathrm{Z}$

Density (calculated)

Absorption coefficient

$\mathrm{F}(000)$

Crystal size

Theta range for data collection

Index ranges

Reflections collected

Independent reflections

Completeness to theta $=67.000^{\circ}$

Absorption correction

Max. and min. transmission

Refinement method

Data / restraints / parameters

Goodness-of-fit on $\mathrm{F}^{2}$

Final $\mathrm{R}$ indices [I $>2 \operatorname{sigma}(\mathrm{I})]$

$\mathrm{R}$ indices (all data)

Extinction coefficient

Largest diff. peak and hole
$\mathrm{C} 27 \mathrm{H} 42 \mathrm{O} 3$

414.60

$100(2) \mathrm{K}$

$1.54178 \AA$

Monoclinic

P 21/n

$\mathrm{a}=6.9326(2) \AA$

$\alpha=90^{\circ}$.

$\mathrm{b}=20.5641(5) \AA$

$\beta=94.577(2)^{\circ}$.

$\mathrm{c}=17.2667(5) \AA$

$\gamma=90^{\circ}$.

2453.74(12) $\AA^{3}$

4

$1.122 \mathrm{Mg} / \mathrm{m}^{3}$

$0.549 \mathrm{~mm}^{-1}$

912

$0.060 \times 0.040 \times 0.010 \mathrm{~mm}^{3}$

3.348 to $68.975^{\circ}$.

$-7<=\mathrm{h}<=8,-24<=\mathrm{k}<=24,-18<=1<=20$

36801

$4502[\mathrm{R}(\mathrm{int})=0.0657]$

$99.8 \%$

Semi-empirical from equivalents

0.929 and 0.860

Full-matrix least-squares on $\mathrm{F}^{2}$

4502 / 0 / 280

1.019

$\mathrm{R} 1=0.0437, \mathrm{wR} 2=0.1054$

$\mathrm{R} 1=0.0678, \mathrm{wR} 2=0.1166$

$\mathrm{n} / \mathrm{a}$

0.232 and -0.190 e. $\AA^{-3}$ 
Table 2. Atomic coordinates $\left(\times 10^{4}\right)$ and equivalent isotropic displacement parameters $\left(\AA^{2} \times 10^{3}\right)$ for 11. $U(e q)$ is defined as one third of the trace of the orthogonalized $U^{\mathrm{ij}}$ tensor.

\begin{tabular}{|c|c|c|c|c|}
\hline & $\mathrm{x}$ & $\mathrm{y}$ & $\mathrm{z}$ & $\mathrm{U}(\mathrm{eq})$ \\
\hline $\mathrm{C}(1)$ & $5312(2)$ & $7285(1)$ & $6547(1)$ & $22(1)$ \\
\hline$C(2)$ & $5177(2)$ & $6576(1)$ & 6910(1) & $24(1)$ \\
\hline$C(3)$ & $3575(2)$ & $6648(1)$ & $7502(1)$ & $24(1)$ \\
\hline$C(4)$ & 2984(2) & $7366(1)$ & 7492(1) & $25(1)$ \\
\hline$C(5)$ & $3343(2)$ & $7606(1)$ & $6683(1)$ & $22(1)$ \\
\hline$C(6)$ & $1767(2)$ & $7377(1)$ & $6077(1)$ & $23(1)$ \\
\hline$C(7)$ & $2256(2)$ & $7274(1)$ & $5285(1)$ & $25(1)$ \\
\hline $\mathrm{C}(8)$ & $4105(2)$ & $7221(1)$ & $5115(1)$ & $23(1)$ \\
\hline $\mathrm{C}(9)$ & $5784(2)$ & $7319(1)$ & $5699(1)$ & $23(1)$ \\
\hline$C(10)$ & $7177(2)$ & $6374(1)$ & $7286(1)$ & $28(1)$ \\
\hline $\mathrm{C}(11)$ & 4495(3) & $6056(1)$ & $6302(1)$ & $27(1)$ \\
\hline$C(12)$ & $4360(3)$ & $5363(1)$ & $6619(1)$ & $33(1)$ \\
\hline$C(13)$ & $3527(3)$ & $4886(1)$ & 6031(1) & $33(1)$ \\
\hline$C(14)$ & 1763(3) & $4624(1)$ & 5981(1) & $36(1)$ \\
\hline$C(15)$ & 241(3) & $4774(1)$ & $6522(2)$ & $52(1)$ \\
\hline$C(16)$ & 1167(3) & 4131(1) & $5365(1)$ & $50(1)$ \\
\hline$C(17)$ & 4041(3) & 6394(1) & $8333(1)$ & $28(1)$ \\
\hline$C(18)$ & $2288(3)$ & $6426(1)$ & $8789(1)$ & $27(1)$ \\
\hline$C(19)$ & 1146(3) & $5938(1)$ & $8962(1)$ & $26(1)$ \\
\hline $\mathrm{C}(20)$ & $-590(3)$ & $6048(1)$ & $9412(1)$ & $33(1)$ \\
\hline$C(21)$ & 1467(3) & $5245(1)$ & $8755(1)$ & $46(1)$ \\
\hline $\mathrm{C}(22)$ & $3379(2)$ & $8360(1)$ & $6623(1)$ & $25(1)$ \\
\hline$C(23)$ & $1618(3)$ & $8686(1)$ & $6899(1)$ & $27(1)$ \\
\hline $\mathrm{C}(24)$ & $146(3)$ & $8946(1)$ & $6469(1)$ & $30(1)$ \\
\hline$C(25)$ & $-59(3)$ & $8947(1)$ & $5598(1)$ & $42(1)$ \\
\hline$C(26)$ & $-1500(3)$ & $9267(1)$ & $6834(1)$ & $41(1)$ \\
\hline $\mathrm{C}(27)$ & $3295(3)$ & 6996(1) & $3773(1)$ & $36(1)$ \\
\hline $\mathrm{O}(1)$ & $6732(2)$ & $7657(1)$ & $7002(1)$ & $25(1)$ \\
\hline $\mathrm{O}(2)$ & $85(2)$ & $7310(1)$ & $6248(1)$ & $28(1)$ \\
\hline $\mathrm{O}(3)$ & $4727(2)$ & 7084(1) & $4412(1)$ & $28(1)$ \\
\hline
\end{tabular}


Table 3. Bond lengths $[\AA]$ and angles $\left[{ }^{\circ}\right]$ for $\mathbf{1 1}$. 


\begin{tabular}{|c|c|c|c|}
\hline $\mathrm{C}(1)-\mathrm{O}(1)$ & $1.431(2)$ & $\mathrm{C}(15)-\mathrm{H}(15 \mathrm{~A})$ & 0.9800 \\
\hline $\mathrm{C}(1)-\mathrm{C}(9)$ & $1.528(2)$ & $\mathrm{C}(15)-\mathrm{H}(15 \mathrm{~B})$ & 0.9800 \\
\hline$C(1)-C(5)$ & $1.551(2)$ & $\mathrm{C}(15)-\mathrm{H}(15 \mathrm{C})$ & 0.9800 \\
\hline $\mathrm{C}(1)-\mathrm{C}(2)$ & $1.593(2)$ & $\mathrm{C}(16)-\mathrm{H}(16 \mathrm{~A})$ & 0.9800 \\
\hline$C(2)-C(10)$ & $1.539(2)$ & $\mathrm{C}(16)-\mathrm{H}(16 \mathrm{~B})$ & 0.9800 \\
\hline$C(2)-C(11)$ & $1.546(2)$ & $\mathrm{C}(16)-\mathrm{H}(16 \mathrm{C})$ & 0.9800 \\
\hline$C(2)-C(3)$ & $1.576(2)$ & $C(17)-C(18)$ & $1.502(2)$ \\
\hline $\mathrm{C}(3)-\mathrm{C}(4)$ & $1.532(2)$ & $\mathrm{C}(17)-\mathrm{H}(17 \mathrm{~A})$ & 0.9900 \\
\hline$C(3)-C(17)$ & $1.536(2)$ & $\mathrm{C}(17)-\mathrm{H}(17 \mathrm{~B})$ & 0.9900 \\
\hline $\mathrm{C}(3)-\mathrm{H}(3)$ & 1.0000 & $C(18)-C(19)$ & $1.327(3)$ \\
\hline $\mathrm{C}(4)-\mathrm{C}(5)$ & $1.521(2)$ & $\mathrm{C}(18)-\mathrm{H}(18)$ & 0.9500 \\
\hline $\mathrm{C}(4)-\mathrm{H}(4 \mathrm{~A})$ & 0.9900 & $C(19)-C(21)$ & $1.491(3)$ \\
\hline $\mathrm{C}(4)-\mathrm{H}(4 \mathrm{~B})$ & 0.9900 & $C(19)-C(20)$ & $1.501(2)$ \\
\hline$C(5)-C(6)$ & $1.527(2)$ & $\mathrm{C}(20)-\mathrm{H}(20 \mathrm{~A})$ & 0.9800 \\
\hline$C(5)-C(22)$ & $1.554(2)$ & $\mathrm{C}(20)-\mathrm{H}(20 \mathrm{~B})$ & 0.9800 \\
\hline $\mathrm{C}(6)-\mathrm{O}(2)$ & $1.234(2)$ & $\mathrm{C}(20)-\mathrm{H}(20 \mathrm{C})$ & 0.9800 \\
\hline$C(6)-C(7)$ & $1.451(2)$ & $\mathrm{C}(21)-\mathrm{H}(21 \mathrm{~A})$ & 0.9800 \\
\hline$C(7)-C(8)$ & $1.342(2)$ & $\mathrm{C}(21)-\mathrm{H}(21 \mathrm{~B})$ & 0.9800 \\
\hline $\mathrm{C}(7)-\mathrm{H}(7)$ & 0.9500 & $\mathrm{C}(21)-\mathrm{H}(21 \mathrm{C})$ & 0.9800 \\
\hline $\mathrm{C}(8)-\mathrm{O}(3)$ & $1.350(2)$ & $C(22)-C(23)$ & $1.503(2)$ \\
\hline $\mathrm{C}(8)-\mathrm{C}(9)$ & $1.491(2)$ & $\mathrm{C}(22)-\mathrm{H}(22 \mathrm{~A})$ & 0.9900 \\
\hline $\mathrm{C}(9)-\mathrm{H}(9 \mathrm{~A})$ & 0.9900 & $\mathrm{C}(22)-\mathrm{H}(22 \mathrm{~B})$ & 0.9900 \\
\hline $\mathrm{C}(9)-\mathrm{H}(9 \mathrm{~B})$ & 0.9900 & $C(23)-C(24)$ & $1.325(3)$ \\
\hline $\mathrm{C}(10)-\mathrm{H}(10 \mathrm{~A})$ & 0.9800 & $\mathrm{C}(23)-\mathrm{H}(23)$ & 0.9500 \\
\hline $\mathrm{C}(10)-\mathrm{H}(10 \mathrm{~B})$ & 0.9800 & $C(24)-C(25)$ & $1.499(3)$ \\
\hline $\mathrm{C}(10)-\mathrm{H}(10 \mathrm{C})$ & 0.9800 & $C(24)-C(26)$ & $1.500(3)$ \\
\hline $\mathrm{C}(11)-\mathrm{C}(12)$ & $1.533(3)$ & $\mathrm{C}(25)-\mathrm{H}(25 \mathrm{~A})$ & 0.9800 \\
\hline $\mathrm{C}(11)-\mathrm{H}(11 \mathrm{~A})$ & 0.9900 & $\mathrm{C}(25)-\mathrm{H}(25 \mathrm{~B})$ & 0.9800 \\
\hline $\mathrm{C}(11)-\mathrm{H}(11 \mathrm{~B})$ & 0.9900 & $\mathrm{C}(25)-\mathrm{H}(25 \mathrm{C})$ & 0.9800 \\
\hline$C(12)-C(13)$ & $1.495(3)$ & $\mathrm{C}(26)-\mathrm{H}(26 \mathrm{~A})$ & 0.9800 \\
\hline $\mathrm{C}(12)-\mathrm{H}(12 \mathrm{~A})$ & 0.9900 & $\mathrm{C}(26)-\mathrm{H}(26 \mathrm{~B})$ & 0.9800 \\
\hline $\mathrm{C}(12)-\mathrm{H}(12 \mathrm{~B})$ & 0.9900 & $\mathrm{C}(26)-\mathrm{H}(26 \mathrm{C})$ & 0.9800 \\
\hline$C(13)-C(14)$ & $1.332(3)$ & $\mathrm{C}(27)-\mathrm{O}(3)$ & $1.435(2)$ \\
\hline $\mathrm{C}(13)-\mathrm{H}(13)$ & 0.9500 & $\mathrm{C}(27)-\mathrm{H}(27 \mathrm{~A})$ & 0.9800 \\
\hline$C(14)-C(15)$ & $1.495(3)$ & $\mathrm{C}(27)-\mathrm{H}(27 \mathrm{~B})$ & 0.9800 \\
\hline C(14)-C(16) & $1.504(3)$ & $\mathrm{C}(27)-\mathrm{H}(27 \mathrm{C})$ & 0.9800 \\
\hline
\end{tabular}




\begin{tabular}{|c|c|c|c|}
\hline $\mathrm{O}(1)-\mathrm{H}(1)$ & 0.8400 & & \\
\hline $\mathrm{O}(1)-\mathrm{C}(1)-\mathrm{C}(9)$ & $108.11(13)$ & $\mathrm{C}(8)-\mathrm{C}(7)-\mathrm{H}(7)$ & 119.4 \\
\hline $\mathrm{O}(1)-\mathrm{C}(1)-\mathrm{C}(5)$ & $105.28(13)$ & $\mathrm{C}(6)-\mathrm{C}(7)-\mathrm{H}(7)$ & 119.4 \\
\hline $\mathrm{C}(9)-\mathrm{C}(1)-\mathrm{C}(5)$ & $112.55(14)$ & $\mathrm{C}(7)-\mathrm{C}(8)-\mathrm{O}(3)$ & $126.31(16)$ \\
\hline $\mathrm{O}(1)-\mathrm{C}(1)-\mathrm{C}(2)$ & $109.49(13)$ & $\mathrm{C}(7)-\mathrm{C}(8)-\mathrm{C}(9)$ & $123.34(16)$ \\
\hline $\mathrm{C}(9)-\mathrm{C}(1)-\mathrm{C}(2)$ & $116.32(14)$ & $\mathrm{O}(3)-\mathrm{C}(8)-\mathrm{C}(9)$ & $110.35(14)$ \\
\hline$C(5)-C(1)-C(2)$ & $104.53(13)$ & $\mathrm{C}(8)-\mathrm{C}(9)-\mathrm{C}(1)$ & $115.22(14)$ \\
\hline $\mathrm{C}(10)-\mathrm{C}(2)-\mathrm{C}(11)$ & $108.44(14)$ & $\mathrm{C}(8)-\mathrm{C}(9)-\mathrm{H}(9 \mathrm{~A})$ & 108.5 \\
\hline$C(10)-C(2)-C(3)$ & $114.19(14)$ & $\mathrm{C}(1)-\mathrm{C}(9)-\mathrm{H}(9 \mathrm{~A})$ & 108.5 \\
\hline $\mathrm{C}(11)-\mathrm{C}(2)-\mathrm{C}(3)$ & $108.22(14)$ & $\mathrm{C}(8)-\mathrm{C}(9)-\mathrm{H}(9 \mathrm{~B})$ & 108.5 \\
\hline $\mathrm{C}(10)-\mathrm{C}(2)-\mathrm{C}(1)$ & $109.46(14)$ & $\mathrm{C}(1)-\mathrm{C}(9)-\mathrm{H}(9 \mathrm{~B})$ & 108.5 \\
\hline $\mathrm{C}(11)-\mathrm{C}(2)-\mathrm{C}(1)$ & $112.95(14)$ & $\mathrm{H}(9 \mathrm{~A})-\mathrm{C}(9)-\mathrm{H}(9 \mathrm{~B})$ & 107.5 \\
\hline $\mathrm{C}(3)-\mathrm{C}(2)-\mathrm{C}(1)$ & $103.62(13)$ & $\mathrm{C}(2)-\mathrm{C}(10)-\mathrm{H}(10 \mathrm{~A})$ & 109.5 \\
\hline $\mathrm{C}(4)-\mathrm{C}(3)-\mathrm{C}(17)$ & $111.96(15)$ & $\mathrm{C}(2)-\mathrm{C}(10)-\mathrm{H}(10 \mathrm{~B})$ & 109.5 \\
\hline$C(4)-C(3)-C(2)$ & $106.57(14)$ & $\mathrm{H}(10 \mathrm{~A})-\mathrm{C}(10)-\mathrm{H}(10 \mathrm{~B})$ & 109.5 \\
\hline $\mathrm{C}(17)-\mathrm{C}(3)-\mathrm{C}(2)$ & $117.87(14)$ & $\mathrm{C}(2)-\mathrm{C}(10)-\mathrm{H}(10 \mathrm{C})$ & 109.5 \\
\hline $\mathrm{C}(4)-\mathrm{C}(3)-\mathrm{H}(3)$ & 106.6 & $\mathrm{H}(10 \mathrm{~A})-\mathrm{C}(10)-\mathrm{H}(10 \mathrm{C})$ & 109.5 \\
\hline $\mathrm{C}(17)-\mathrm{C}(3)-\mathrm{H}(3)$ & 106.6 & $\mathrm{H}(10 \mathrm{~B})-\mathrm{C}(10)-\mathrm{H}(10 \mathrm{C})$ & 109.5 \\
\hline $\mathrm{C}(2)-\mathrm{C}(3)-\mathrm{H}(3)$ & 106.6 & $\mathrm{C}(12)-\mathrm{C}(11)-\mathrm{C}(2)$ & $115.08(15)$ \\
\hline$C(5)-C(4)-C(3)$ & $105.11(14)$ & $\mathrm{C}(12)-\mathrm{C}(11)-\mathrm{H}(11 \mathrm{~A})$ & 108.5 \\
\hline $\mathrm{C}(5)-\mathrm{C}(4)-\mathrm{H}(4 \mathrm{~A})$ & 110.7 & $\mathrm{C}(2)-\mathrm{C}(11)-\mathrm{H}(11 \mathrm{~A})$ & 108.5 \\
\hline $\mathrm{C}(3)-\mathrm{C}(4)-\mathrm{H}(4 \mathrm{~A})$ & 110.7 & $\mathrm{C}(12)-\mathrm{C}(11)-\mathrm{H}(11 \mathrm{~B})$ & 108.5 \\
\hline $\mathrm{C}(5)-\mathrm{C}(4)-\mathrm{H}(4 \mathrm{~B})$ & 110.7 & $\mathrm{C}(2)-\mathrm{C}(11)-\mathrm{H}(11 \mathrm{~B})$ & 108.5 \\
\hline $\mathrm{C}(3)-\mathrm{C}(4)-\mathrm{H}(4 \mathrm{~B})$ & 110.7 & $\mathrm{H}(11 \mathrm{~A})-\mathrm{C}(11)-\mathrm{H}(11 \mathrm{~B})$ & 107.5 \\
\hline $\mathrm{H}(4 \mathrm{~A})-\mathrm{C}(4)-\mathrm{H}(4 \mathrm{~B})$ & 108.8 & $\mathrm{C}(13)-\mathrm{C}(12)-\mathrm{C}(11)$ & $113.48(16)$ \\
\hline$C(4)-C(5)-C(6)$ & $111.62(14)$ & $\mathrm{C}(13)-\mathrm{C}(12)-\mathrm{H}(12 \mathrm{~A})$ & 108.9 \\
\hline $\mathrm{C}(4)-\mathrm{C}(5)-\mathrm{C}(1)$ & $102.16(13)$ & $\mathrm{C}(11)-\mathrm{C}(12)-\mathrm{H}(12 \mathrm{~A})$ & 108.9 \\
\hline$C(6)-C(5)-C(1)$ & $110.76(14)$ & $\mathrm{C}(13)-\mathrm{C}(12)-\mathrm{H}(12 \mathrm{~B})$ & 108.9 \\
\hline$C(4)-C(5)-C(22)$ & $113.00(14)$ & $\mathrm{C}(11)-\mathrm{C}(12)-\mathrm{H}(12 \mathrm{~B})$ & 108.9 \\
\hline$C(6)-C(5)-C(22)$ & $106.07(13)$ & $\mathrm{H}(12 \mathrm{~A})-\mathrm{C}(12)-\mathrm{H}(12 \mathrm{~B})$ & 107.7 \\
\hline$C(1)-C(5)-C(22)$ & $113.36(13)$ & $\mathrm{C}(14)-\mathrm{C}(13)-\mathrm{C}(12)$ & $127.68(19)$ \\
\hline $\mathrm{O}(2)-\mathrm{C}(6)-\mathrm{C}(7)$ & $120.46(16)$ & $\mathrm{C}(14)-\mathrm{C}(13)-\mathrm{H}(13)$ & 116.2 \\
\hline $\mathrm{O}(2)-\mathrm{C}(6)-\mathrm{C}(5)$ & $120.55(16)$ & $\mathrm{C}(12)-\mathrm{C}(13)-\mathrm{H}(13)$ & 116.2 \\
\hline$C(7)-C(6)-C(5)$ & $118.89(14)$ & $\mathrm{C}(13)-\mathrm{C}(14)-\mathrm{C}(15)$ & $124.5(2)$ \\
\hline $\mathrm{C}(8)-\mathrm{C}(7)-\mathrm{C}(6)$ & $121.11(15)$ & $\mathrm{C}(13)-\mathrm{C}(14)-\mathrm{C}(16)$ & $121.10(19)$ \\
\hline
\end{tabular}




\begin{tabular}{|c|c|c|c|}
\hline$C(15)-C(14)-C(16)$ & $114.37(18)$ & $\mathrm{H}(21 \mathrm{~B})-\mathrm{C}(21)-\mathrm{H}(21 \mathrm{C})$ & 109.5 \\
\hline $\mathrm{C}(14)-\mathrm{C}(15)-\mathrm{H}(15 \mathrm{~A})$ & 109.5 & $C(23)-C(22)-C(5)$ & $113.98(14)$ \\
\hline $\mathrm{C}(14)-\mathrm{C}(15)-\mathrm{H}(15 \mathrm{~B})$ & 109.5 & $\mathrm{C}(23)-\mathrm{C}(22)-\mathrm{H}(22 \mathrm{~A})$ & 108.8 \\
\hline $\mathrm{H}(15 \mathrm{~A})-\mathrm{C}(15)-\mathrm{H}(15 \mathrm{~B})$ & 109.5 & $\mathrm{C}(5)-\mathrm{C}(22)-\mathrm{H}(22 \mathrm{~A})$ & 108.8 \\
\hline $\mathrm{C}(14)-\mathrm{C}(15)-\mathrm{H}(15 \mathrm{C})$ & 109.5 & $\mathrm{C}(23)-\mathrm{C}(22)-\mathrm{H}(22 \mathrm{~B})$ & 108.8 \\
\hline $\mathrm{H}(15 \mathrm{~A})-\mathrm{C}(15)-\mathrm{H}(15 \mathrm{C})$ & 109.5 & $\mathrm{C}(5)-\mathrm{C}(22)-\mathrm{H}(22 \mathrm{~B})$ & 108.8 \\
\hline $\mathrm{H}(15 \mathrm{~B})-\mathrm{C}(15)-\mathrm{H}(15 \mathrm{C})$ & 109.5 & $\mathrm{H}(22 \mathrm{~A})-\mathrm{C}(22)-\mathrm{H}(22 \mathrm{~B})$ & 107.7 \\
\hline $\mathrm{C}(14)-\mathrm{C}(16)-\mathrm{H}(16 \mathrm{~A})$ & 109.5 & $\mathrm{C}(24)-\mathrm{C}(23)-\mathrm{C}(22)$ & $127.66(18)$ \\
\hline $\mathrm{C}(14)-\mathrm{C}(16)-\mathrm{H}(16 \mathrm{~B})$ & 109.5 & $\mathrm{C}(24)-\mathrm{C}(23)-\mathrm{H}(23)$ & 116.2 \\
\hline $\mathrm{H}(16 \mathrm{~A})-\mathrm{C}(16)-\mathrm{H}(16 \mathrm{~B})$ & 109.5 & $\mathrm{C}(22)-\mathrm{C}(23)-\mathrm{H}(23)$ & 116.2 \\
\hline $\mathrm{C}(14)-\mathrm{C}(16)-\mathrm{H}(16 \mathrm{C})$ & 109.5 & $\mathrm{C}(23)-\mathrm{C}(24)-\mathrm{C}(25)$ & $124.70(18)$ \\
\hline $\mathrm{H}(16 \mathrm{~A})-\mathrm{C}(16)-\mathrm{H}(16 \mathrm{C})$ & 109.5 & $C(23)-C(24)-C(26)$ & $121.28(19)$ \\
\hline $\mathrm{H}(16 \mathrm{~B})-\mathrm{C}(16)-\mathrm{H}(16 \mathrm{C})$ & 109.5 & $C(25)-C(24)-C(26)$ & $114.01(17)$ \\
\hline C(18)-C(17)-C(3) & $110.88(14)$ & $\mathrm{C}(24)-\mathrm{C}(25)-\mathrm{H}(25 \mathrm{~A})$ & 109.5 \\
\hline $\mathrm{C}(18)-\mathrm{C}(17)-\mathrm{H}(17 \mathrm{~A})$ & 109.5 & $\mathrm{C}(24)-\mathrm{C}(25)-\mathrm{H}(25 \mathrm{~B})$ & 109.5 \\
\hline $\mathrm{C}(3)-\mathrm{C}(17)-\mathrm{H}(17 \mathrm{~A})$ & 109.5 & $\mathrm{H}(25 \mathrm{~A})-\mathrm{C}(25)-\mathrm{H}(25 \mathrm{~B})$ & 109.5 \\
\hline $\mathrm{C}(18)-\mathrm{C}(17)-\mathrm{H}(17 \mathrm{~B})$ & 109.5 & $\mathrm{C}(24)-\mathrm{C}(25)-\mathrm{H}(25 \mathrm{C})$ & 109.5 \\
\hline $\mathrm{C}(3)-\mathrm{C}(17)-\mathrm{H}(17 \mathrm{~B})$ & 109.5 & $\mathrm{H}(25 \mathrm{~A})-\mathrm{C}(25)-\mathrm{H}(25 \mathrm{C})$ & 109.5 \\
\hline $\mathrm{H}(17 \mathrm{~A})-\mathrm{C}(17)-\mathrm{H}(17 \mathrm{~B})$ & 108.1 & $\mathrm{H}(25 \mathrm{~B})-\mathrm{C}(25)-\mathrm{H}(25 \mathrm{C})$ & 109.5 \\
\hline $\mathrm{C}(19)-\mathrm{C}(18)-\mathrm{C}(17)$ & $127.39(17)$ & $\mathrm{C}(24)-\mathrm{C}(26)-\mathrm{H}(26 \mathrm{~A})$ & 109.5 \\
\hline $\mathrm{C}(19)-\mathrm{C}(18)-\mathrm{H}(18)$ & 116.3 & $\mathrm{C}(24)-\mathrm{C}(26)-\mathrm{H}(26 \mathrm{~B})$ & 109.5 \\
\hline $\mathrm{C}(17)-\mathrm{C}(18)-\mathrm{H}(18)$ & 116.3 & $\mathrm{H}(26 \mathrm{~A})-\mathrm{C}(26)-\mathrm{H}(26 \mathrm{~B})$ & 109.5 \\
\hline $\mathrm{C}(18)-\mathrm{C}(19)-\mathrm{C}(21)$ & $124.46(18)$ & $\mathrm{C}(24)-\mathrm{C}(26)-\mathrm{H}(26 \mathrm{C})$ & 109.5 \\
\hline$C(18)-C(19)-C(20)$ & $121.36(17)$ & $\mathrm{H}(26 \mathrm{~A})-\mathrm{C}(26)-\mathrm{H}(26 \mathrm{C})$ & 109.5 \\
\hline $\mathrm{C}(21)-\mathrm{C}(19)-\mathrm{C}(20)$ & $114.16(16)$ & $\mathrm{H}(26 \mathrm{~B})-\mathrm{C}(26)-\mathrm{H}(26 \mathrm{C})$ & 109.5 \\
\hline $\mathrm{C}(19)-\mathrm{C}(20)-\mathrm{H}(20 \mathrm{~A})$ & 109.5 & $\mathrm{O}(3)-\mathrm{C}(27)-\mathrm{H}(27 \mathrm{~A})$ & 109.5 \\
\hline C(19)-C(20)-H(20B) & 109.5 & $\mathrm{O}(3)-\mathrm{C}(27)-\mathrm{H}(27 \mathrm{~B})$ & 109.5 \\
\hline $\mathrm{H}(20 \mathrm{~A})-\mathrm{C}(20)-\mathrm{H}(20 \mathrm{~B})$ & 109.5 & $\mathrm{H}(27 \mathrm{~A})-\mathrm{C}(27)-\mathrm{H}(27 \mathrm{~B})$ & 109.5 \\
\hline C(19)-C(20)-H(20C) & 109.5 & $\mathrm{O}(3)-\mathrm{C}(27)-\mathrm{H}(27 \mathrm{C})$ & 109.5 \\
\hline $\mathrm{H}(20 \mathrm{~A})-\mathrm{C}(20)-\mathrm{H}(20 \mathrm{C})$ & 109.5 & $\mathrm{H}(27 \mathrm{~A})-\mathrm{C}(27)-\mathrm{H}(27 \mathrm{C})$ & 109.5 \\
\hline $\mathrm{H}(20 \mathrm{~B})-\mathrm{C}(20)-\mathrm{H}(20 \mathrm{C})$ & 109.5 & $\mathrm{H}(27 \mathrm{~B})-\mathrm{C}(27)-\mathrm{H}(27 \mathrm{C})$ & 109.5 \\
\hline $\mathrm{C}(19)-\mathrm{C}(21)-\mathrm{H}(21 \mathrm{~A})$ & 109.5 & $\mathrm{C}(1)-\mathrm{O}(1)-\mathrm{H}(1)$ & 109.5 \\
\hline $\mathrm{C}(19)-\mathrm{C}(21)-\mathrm{H}(21 \mathrm{~B})$ & 109.5 & $\mathrm{C}(8)-\mathrm{O}(3)-\mathrm{C}(27)$ & $117.81(14)$ \\
\hline $\mathrm{H}(21 \mathrm{~A})-\mathrm{C}(21)-\mathrm{H}(21 \mathrm{~B})$ & 109.5 & & \\
\hline $\mathrm{C}(19)-\mathrm{C}(21)-\mathrm{H}(21 \mathrm{C})$ & 109.5 & & \\
\hline $\mathrm{H}(21 \mathrm{~A})-\mathrm{C}(21)-\mathrm{H}(21 \mathrm{C})$ & 109.5 & \multicolumn{2}{|c|}{ Symmetry transformations used to generate } \\
\hline
\end{tabular}


equivalent atoms: 
Table 4. Anisotropic displacement parameters $\left(\AA^{2} \times 10^{3}\right)$ for 11. The anisotropic displacement factor exponent takes the form: $-2 \pi^{2}\left[h^{2} a^{* 2} U^{11}+\ldots+2 h k a^{*} b^{*} U^{12}\right]$

\begin{tabular}{|c|c|c|c|c|c|c|}
\hline & $\mathrm{U}^{11}$ & $\mathrm{U}^{22}$ & $\mathrm{U}^{33}$ & $\mathrm{U}^{23}$ & $\mathrm{U}^{13}$ & $\mathrm{U}^{12}$ \\
\hline $\mathrm{C}(1)$ & $20(1)$ & $22(1)$ & $24(1)$ & $0(1)$ & $2(1)$ & $-2(1)$ \\
\hline$C(2)$ & $20(1)$ & $24(1)$ & $27(1)$ & $3(1)$ & $1(1)$ & $1(1)$ \\
\hline$C(3)$ & $20(1)$ & $23(1)$ & $29(1)$ & $3(1)$ & $1(1)$ & $-1(1)$ \\
\hline$C(4)$ & $23(1)$ & $25(1)$ & $26(1)$ & 1(1) & $4(1)$ & $1(1)$ \\
\hline$C(5)$ & 19(1) & $23(1)$ & $26(1)$ & $1(1)$ & $3(1)$ & $-1(1)$ \\
\hline$C(6)$ & $20(1)$ & $18(1)$ & $32(1)$ & $4(1)$ & $3(1)$ & $1(1)$ \\
\hline$C(7)$ & $22(1)$ & $24(1)$ & $27(1)$ & $2(1)$ & $-3(1)$ & $-2(1)$ \\
\hline$C(8)$ & $26(1)$ & $18(1)$ & $26(1)$ & $1(1)$ & $2(1)$ & $-3(1)$ \\
\hline$C(9)$ & $18(1)$ & $22(1)$ & $28(1)$ & $0(1)$ & $3(1)$ & $-1(1)$ \\
\hline$C(10)$ & $22(1)$ & $29(1)$ & $33(1)$ & $6(1)$ & $2(1)$ & $1(1)$ \\
\hline$C(11)$ & $27(1)$ & $24(1)$ & $30(1)$ & $2(1)$ & $4(1)$ & 1(1) \\
\hline$C(12)$ & $34(1)$ & $25(1)$ & $38(1)$ & $4(1)$ & $3(1)$ & $0(1)$ \\
\hline$C(13)$ & $36(1)$ & $24(1)$ & $42(1)$ & $-1(1)$ & $12(1)$ & $1(1)$ \\
\hline$C(14)$ & $37(1)$ & $28(1)$ & $43(1)$ & $-1(1)$ & $9(1)$ & $-1(1)$ \\
\hline$C(15)$ & $39(1)$ & $63(2)$ & $57(1)$ & $-14(1)$ & 11(1) & $-5(1)$ \\
\hline$C(16)$ & $49(1)$ & $42(1)$ & $61(2)$ & $-14(1)$ & $15(1)$ & $-13(1)$ \\
\hline$C(17)$ & $27(1)$ & $26(1)$ & $30(1)$ & $4(1)$ & $1(1)$ & $-1(1)$ \\
\hline$C(18)$ & $34(1)$ & $24(1)$ & $24(1)$ & $2(1)$ & $4(1)$ & $3(1)$ \\
\hline$C(19)$ & $28(1)$ & $25(1)$ & $26(1)$ & $3(1)$ & $1(1)$ & $2(1)$ \\
\hline$C(20)$ & $35(1)$ & $32(1)$ & $33(1)$ & $5(1)$ & $9(1)$ & $1(1)$ \\
\hline$C(21)$ & $48(1)$ & $29(1)$ & $64(2)$ & $0(1)$ & $23(1)$ & $-3(1)$ \\
\hline $\mathrm{C}(22)$ & $20(1)$ & $23(1)$ & $32(1)$ & $1(1)$ & $1(1)$ & $-2(1)$ \\
\hline$C(23)$ & $29(1)$ & $20(1)$ & $32(1)$ & $-1(1)$ & $6(1)$ & $-3(1)$ \\
\hline$C(24)$ & $25(1)$ & $20(1)$ & $43(1)$ & $-2(1)$ & $2(1)$ & $-5(1)$ \\
\hline$C(25)$ & $37(1)$ & $40(1)$ & $46(1)$ & $5(1)$ & $-10(1)$ & $3(1)$ \\
\hline$C(26)$ & $29(1)$ & $25(1)$ & $69(2)$ & $-5(1)$ & $6(1)$ & 1(1) \\
\hline$C(27)$ & $33(1)$ & $45(1)$ & $29(1)$ & $-4(1)$ & $-3(1)$ & $-3(1)$ \\
\hline $\mathrm{O}(1)$ & $18(1)$ & $28(1)$ & $29(1)$ & $-3(1)$ & $-1(1)$ & $-2(1)$ \\
\hline $\mathrm{O}(2)$ & $19(1)$ & $30(1)$ & $37(1)$ & $2(1)$ & $4(1)$ & $-1(1)$ \\
\hline $\mathrm{O}(3)$ & $27(1)$ & $33(1)$ & $23(1)$ & $-1(1)$ & $1(1)$ & $-2(1)$ \\
\hline
\end{tabular}


Table 5. Hydrogen coordinates ( $\left.\times 10^{4}\right)$ and isotropic displacement parameters $\left(\AA^{2} \times 10^{3}\right)$ for maimone 55 .

\begin{tabular}{|c|c|c|c|c|}
\hline & $\mathrm{x}$ & $\mathrm{y}$ & z & $\mathrm{U}(\mathrm{eq})$ \\
\hline $\mathrm{H}(3)$ & 2423 & 6398 & 7280 & 29 \\
\hline $\mathrm{H}(4 \mathrm{~A})$ & 1602 & 7413 & 7589 & 30 \\
\hline $\mathrm{H}(4 \mathrm{~B})$ & 3777 & 7613 & 7894 & 30 \\
\hline $\mathrm{H}(7)$ & 1251 & 7244 & 4879 & 29 \\
\hline $\mathrm{H}(9 \mathrm{~A})$ & 6362 & 7750 & 5606 & 27 \\
\hline $\mathrm{H}(9 \mathrm{~B})$ & 6774 & 6986 & 5612 & 27 \\
\hline $\mathrm{H}(10 \mathrm{~A})$ & 7091 & 5939 & 7514 & 42 \\
\hline $\mathrm{H}(10 \mathrm{~B})$ & 7600 & 6686 & 7693 & 42 \\
\hline $\mathrm{H}(10 \mathrm{C})$ & 8112 & 6368 & 6889 & 42 \\
\hline $\mathrm{H}(11 \mathrm{~A})$ & 3205 & 6184 & 6062 & 32 \\
\hline $\mathrm{H}(11 \mathrm{~B})$ & 5399 & 6055 & 5886 & 32 \\
\hline $\mathrm{H}(12 \mathrm{~A})$ & 5671 & 5216 & 6812 & 39 \\
\hline $\mathrm{H}(12 \mathrm{~B})$ & 3548 & 5368 & 7066 & 39 \\
\hline $\mathrm{H}(13)$ & 4353 & 4754 & 5647 & 40 \\
\hline $\mathrm{H}(15 \mathrm{~A})$ & 677 & 5134 & 6864 & 78 \\
\hline $\mathrm{H}(15 \mathrm{~B})$ & 10 & 4389 & 6836 & 78 \\
\hline $\mathrm{H}(15 \mathrm{C})$ & -960 & 4897 & 6220 & 78 \\
\hline $\mathrm{H}(16 \mathrm{~A})$ & 2183 & 4093 & 5004 & 75 \\
\hline $\mathrm{H}(16 \mathrm{~B})$ & -41 & 4270 & 5080 & 75 \\
\hline $\mathrm{H}(16 \mathrm{C})$ & 972 & 3708 & 5609 & 75 \\
\hline $\mathrm{H}(17 \mathrm{~A})$ & 4496 & 5938 & 8313 & 33 \\
\hline $\mathrm{H}(17 \mathrm{~B})$ & 5093 & 6658 & 8595 & 33 \\
\hline $\mathrm{H}(18)$ & 1958 & 6843 & 8975 & 33 \\
\hline $\mathrm{H}(20 \mathrm{~A})$ & -402 & 5827 & 9915 & 50 \\
\hline $\mathrm{H}(20 \mathrm{~B})$ & -1744 & 5873 & 9119 & 50 \\
\hline $\mathrm{H}(20 \mathrm{C})$ & -758 & 6515 & 9496 & 50 \\
\hline $\mathrm{H}(21 \mathrm{~A})$ & 2628 & 5211 & 8469 & 69 \\
\hline $\mathrm{H}(21 \mathrm{~B})$ & 345 & 5084 & 8430 & 69 \\
\hline $\mathrm{H}(21 \mathrm{C})$ & 1640 & 4984 & 9230 & 69 \\
\hline $\mathrm{H}(22 \mathrm{~A})$ & 4539 & 8525 & 6933 & 30 \\
\hline
\end{tabular}




\begin{tabular}{lrlll}
$\mathrm{H}(22 \mathrm{~B})$ & 3499 & 8483 & 6075 & 30 \\
$\mathrm{H}(23)$ & 1552 & 8709 & 7445 & 32 \\
$\mathrm{H}(25 \mathrm{~A})$ & 1075 & 8738 & 5401 & 63 \\
$\mathrm{H}(25 \mathrm{~B})$ & -157 & 9396 & 5409 & 63 \\
$\mathrm{H}(25 \mathrm{C})$ & -1229 & 8707 & 5414 & 63 \\
$\mathrm{H}(26 \mathrm{~A})$ & -1310 & 9224 & 7400 & 62 \\
$\mathrm{H}(26 \mathrm{~B})$ & -2719 & 9058 & 6647 & 62 \\
$\mathrm{H}(26 \mathrm{C})$ & -1546 & 9729 & 6694 & 62 \\
$\mathrm{H}(27 \mathrm{~A})$ & 2442 & 6634 & 3887 & 54 \\
$\mathrm{H}(27 \mathrm{~B})$ & 3937 & 6899 & 3301 & 54 \\
$\mathrm{H}(27 \mathrm{C})$ & 2529 & 7394 & 3696 & 54 \\
$\mathrm{H}(1)$ & 7834 & 7580 & 6854 & 38 \\
& & & & \\
\hline
\end{tabular}




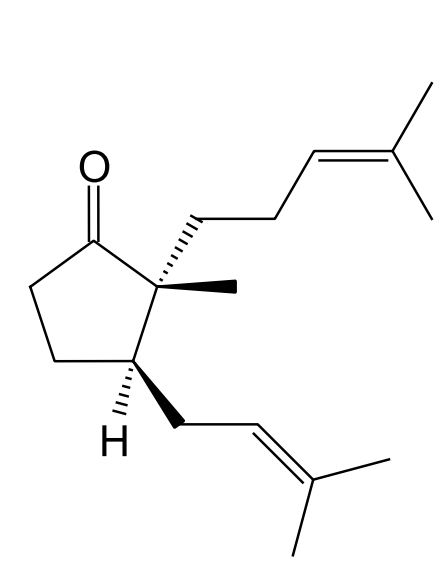




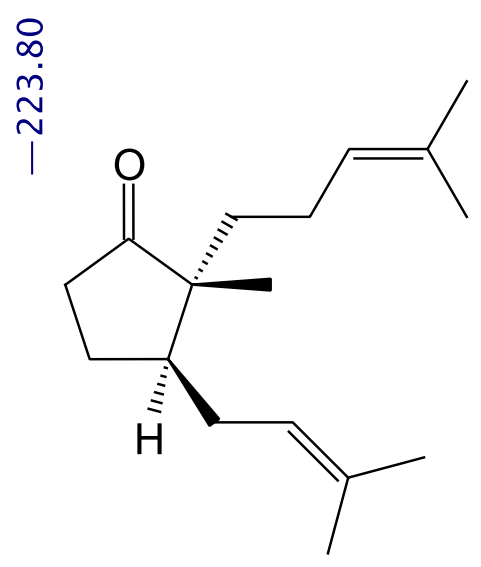




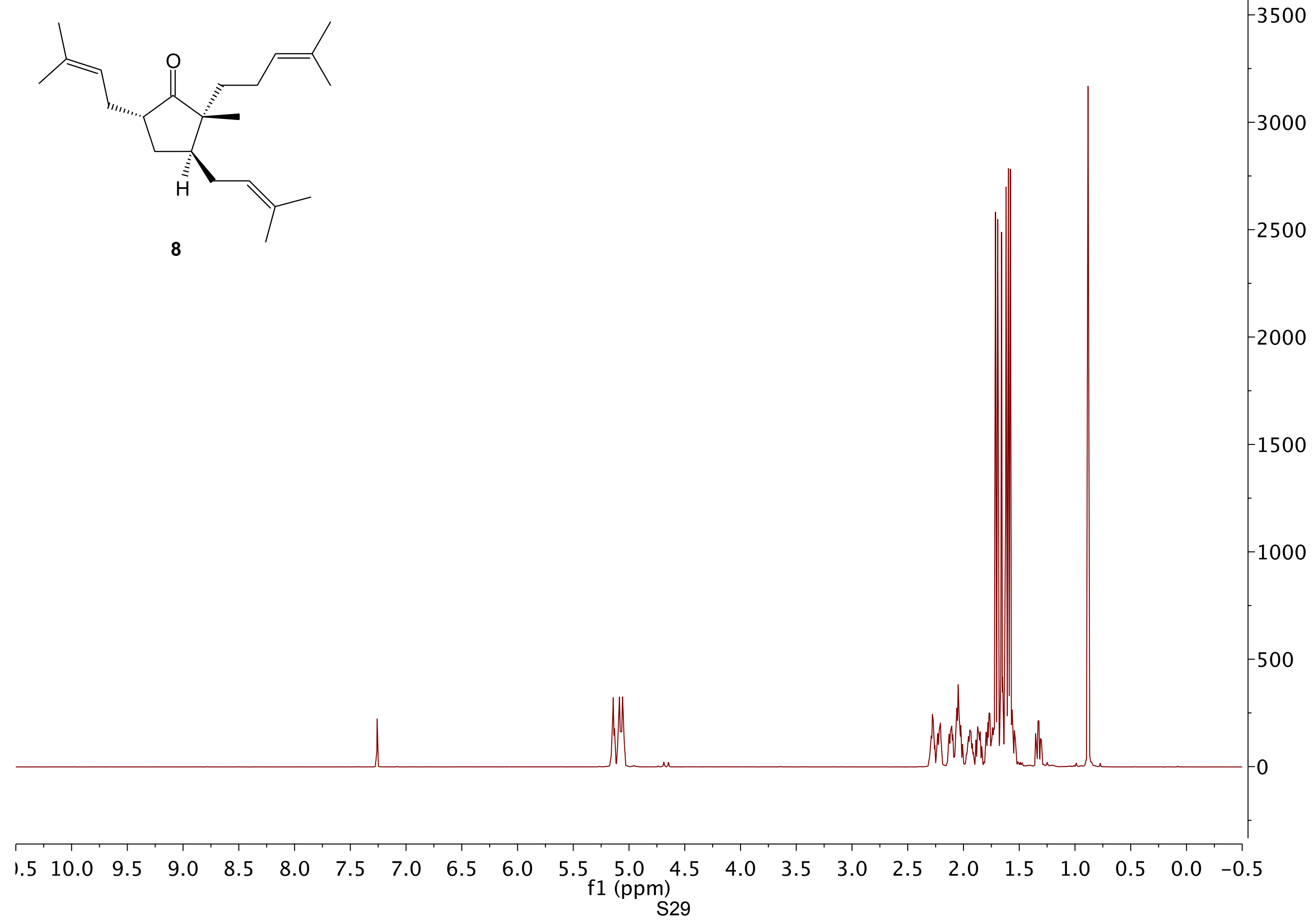




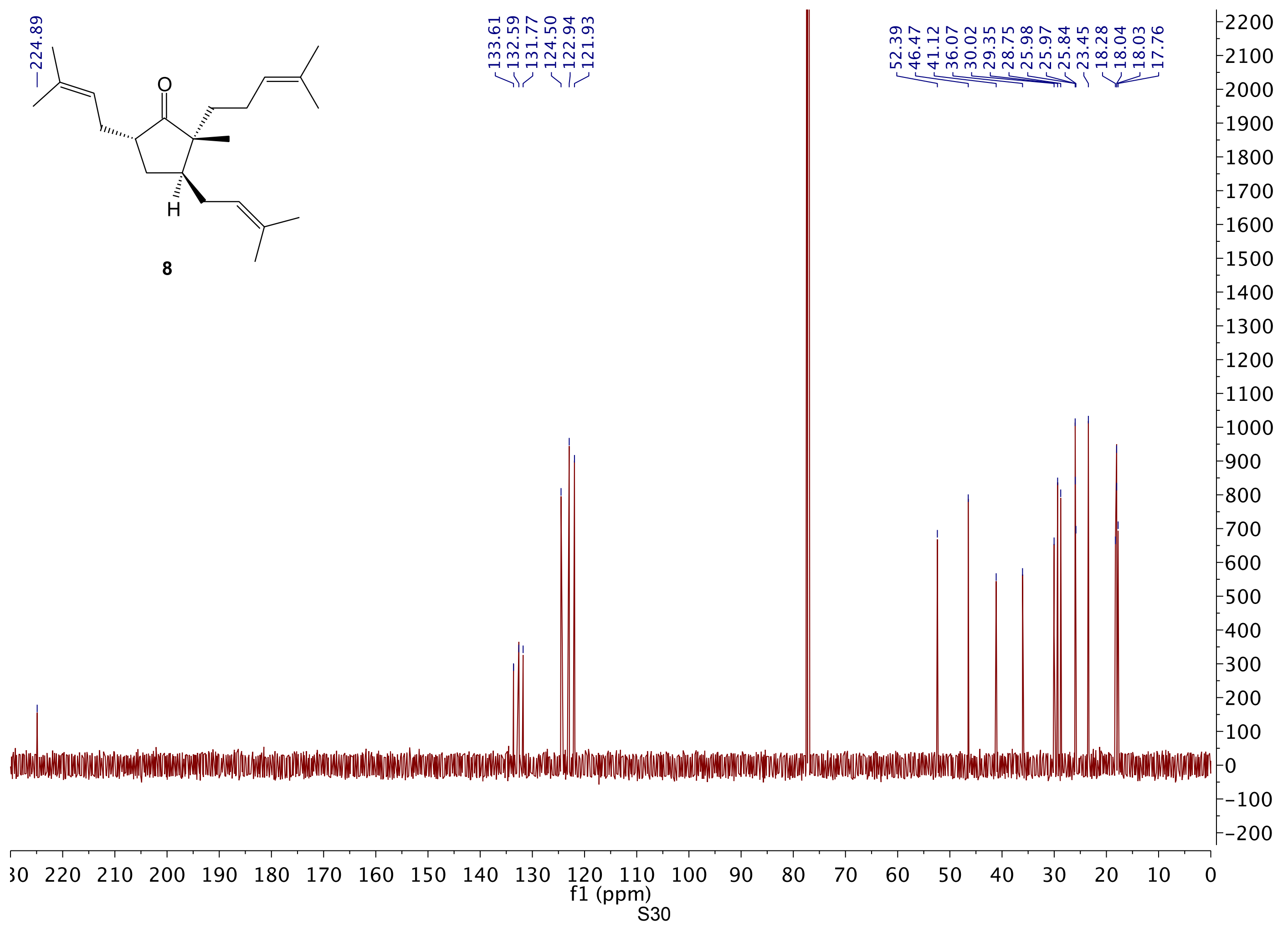




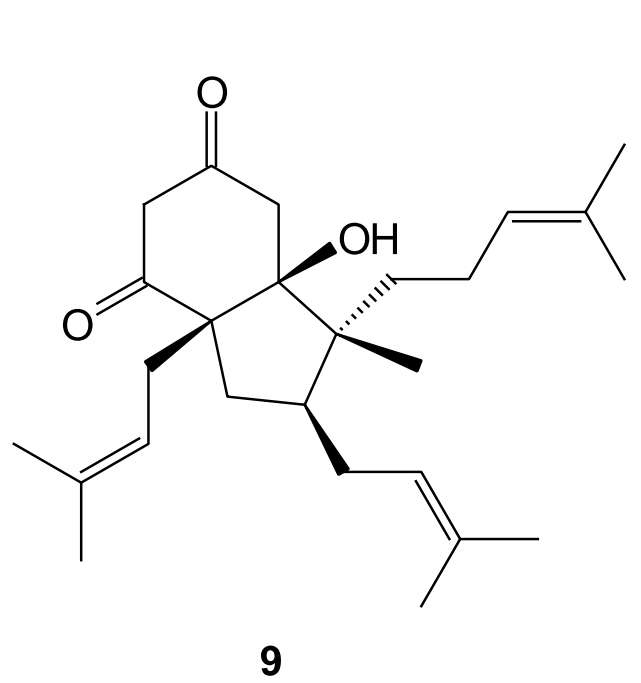




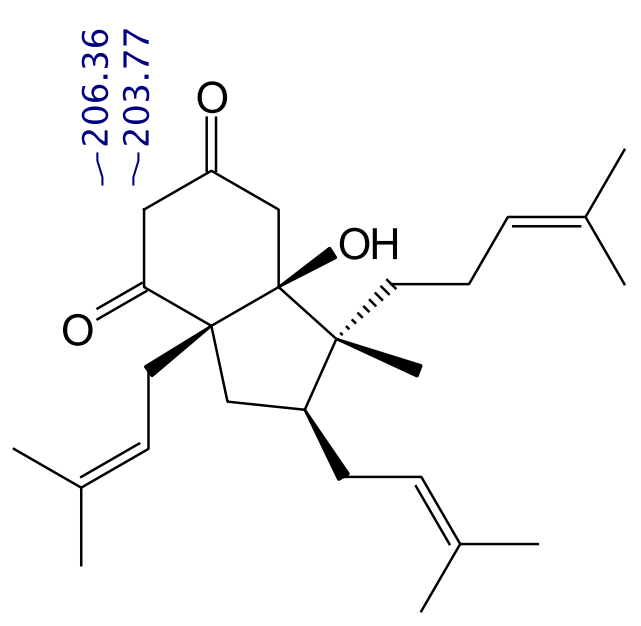

9

ப் ப்ंல்

। $-6000$ 


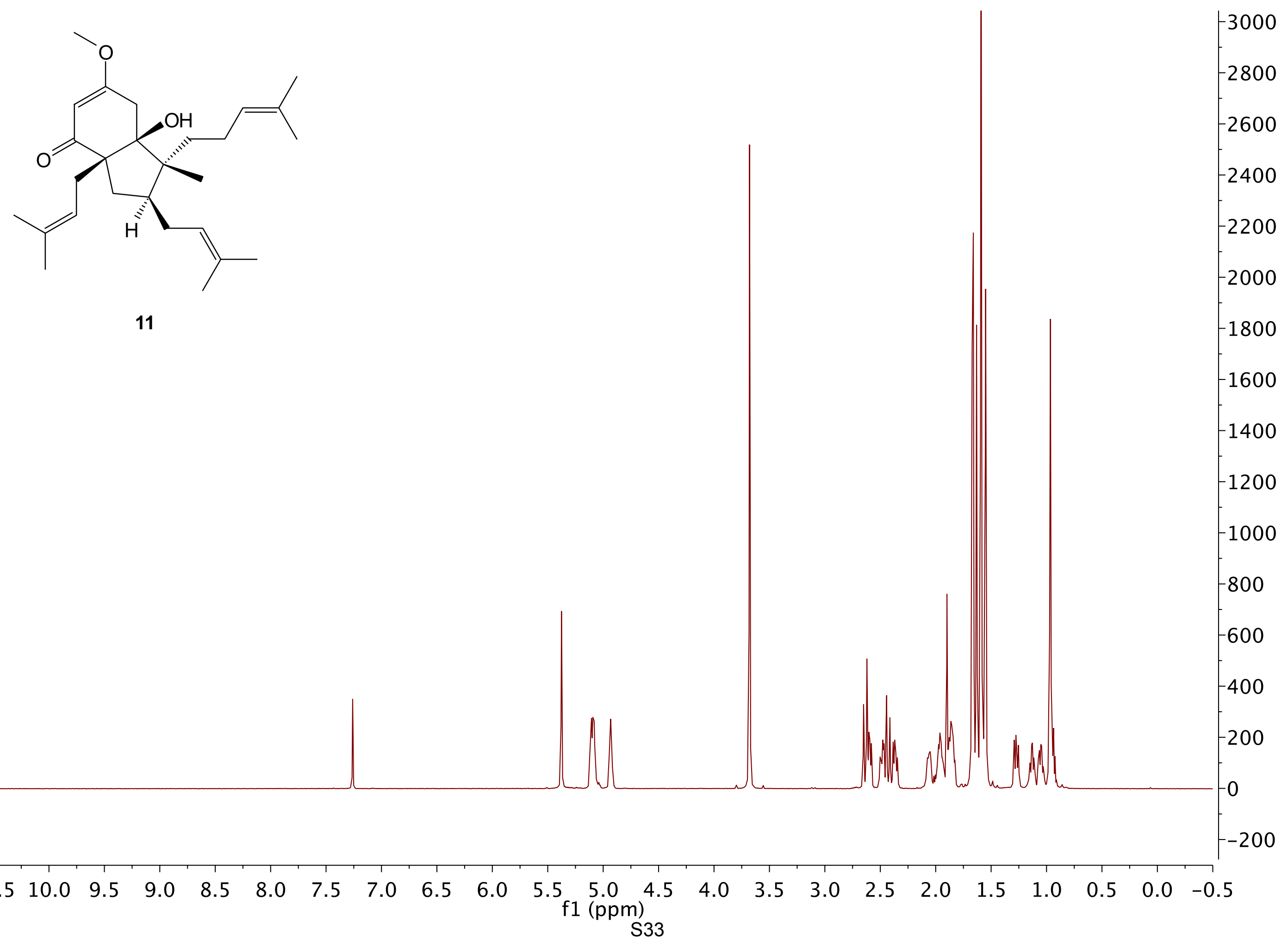




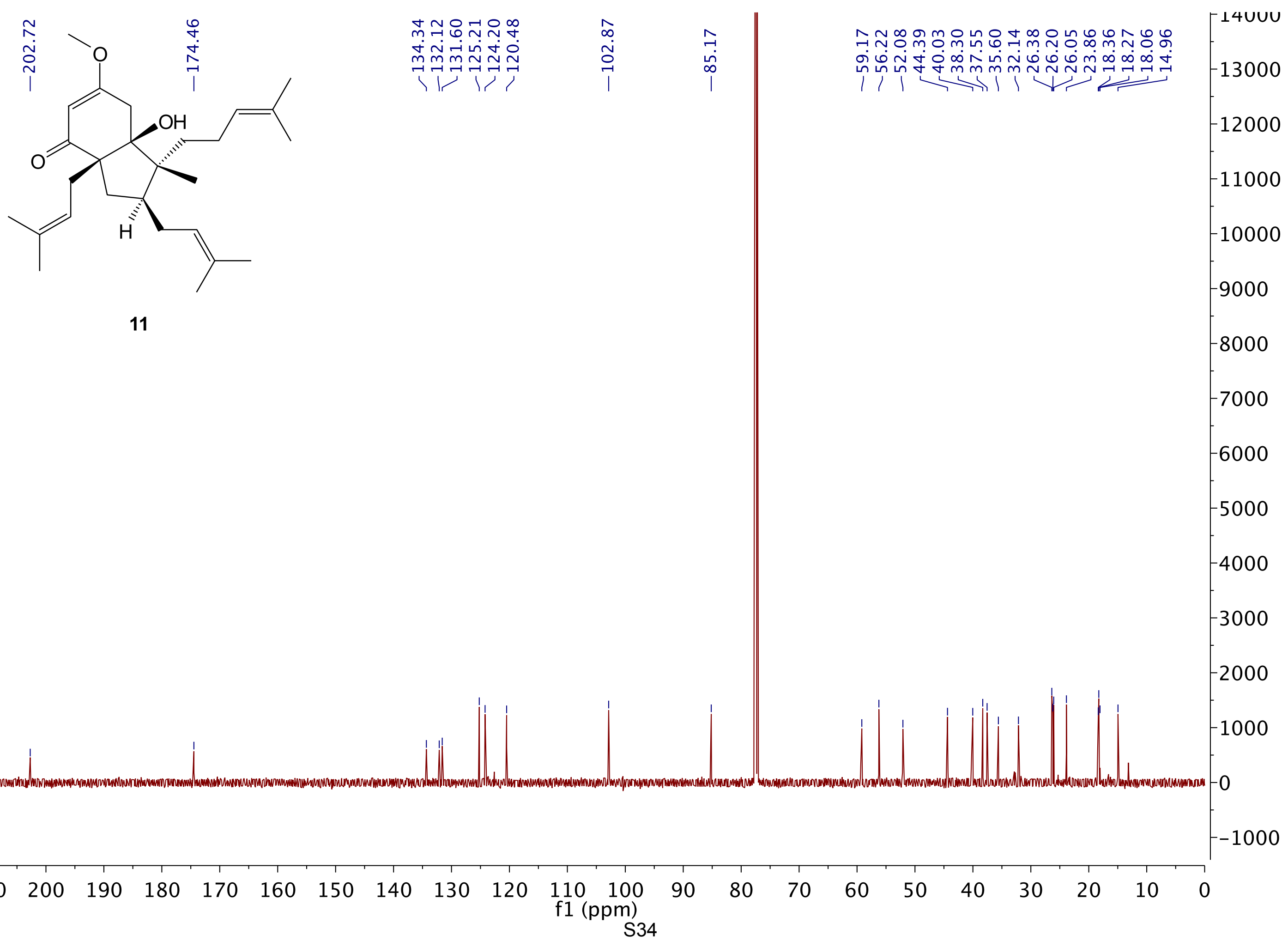




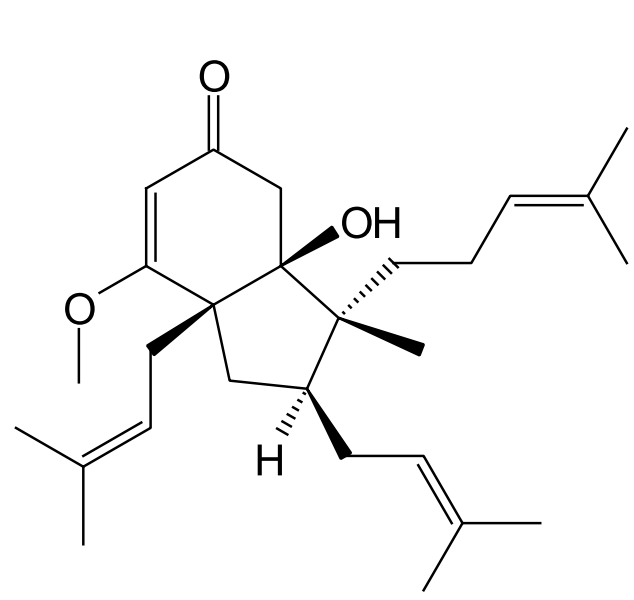



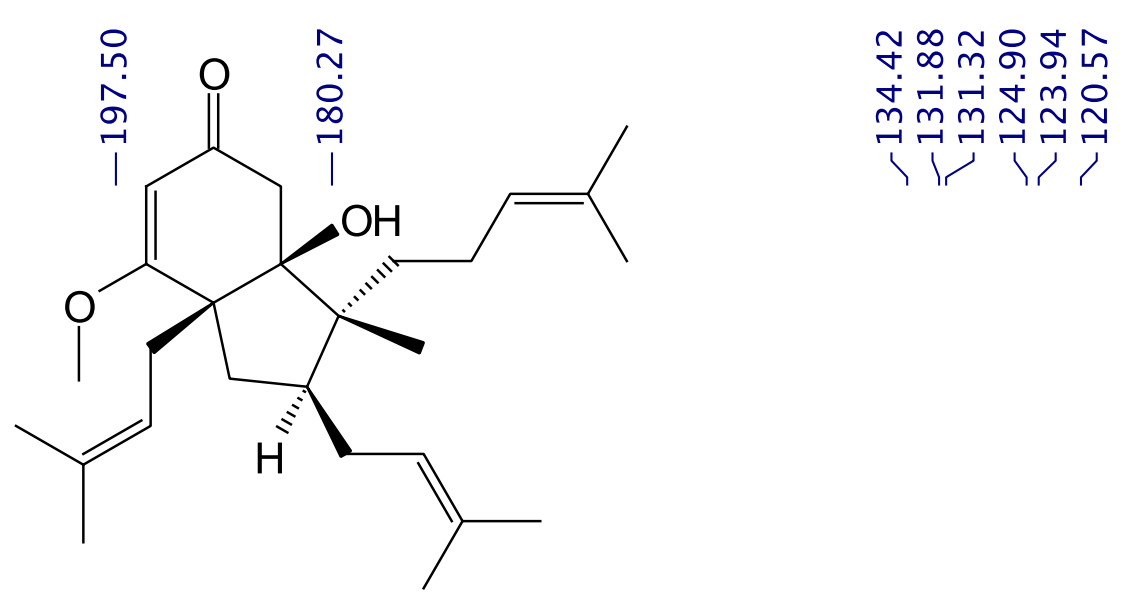

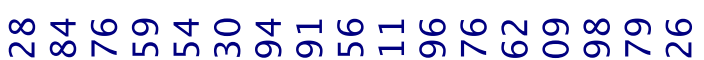

...
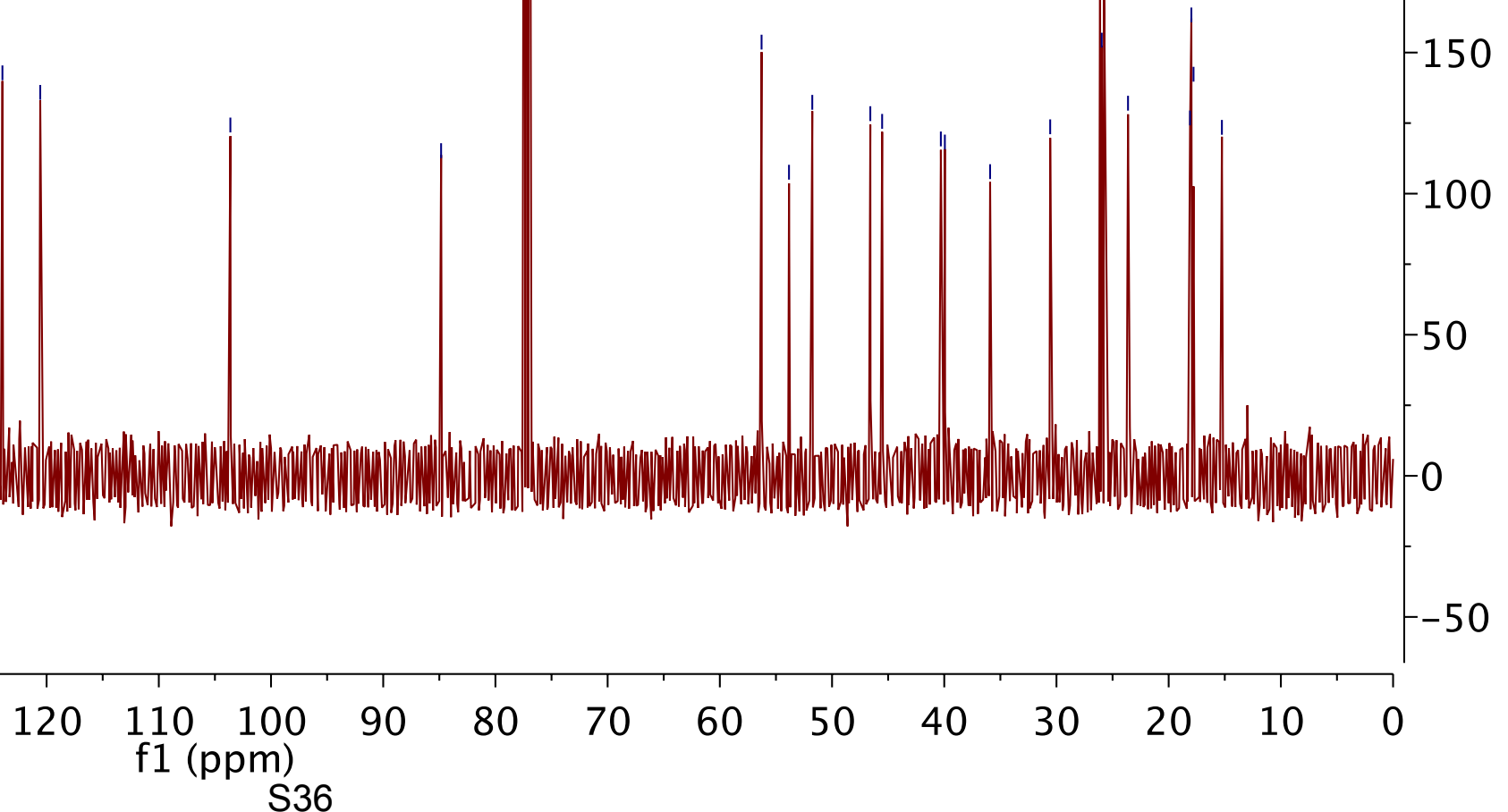


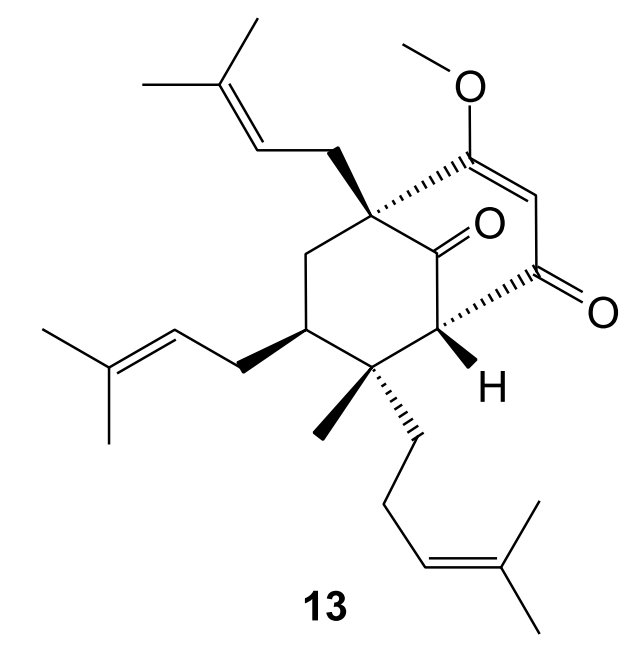




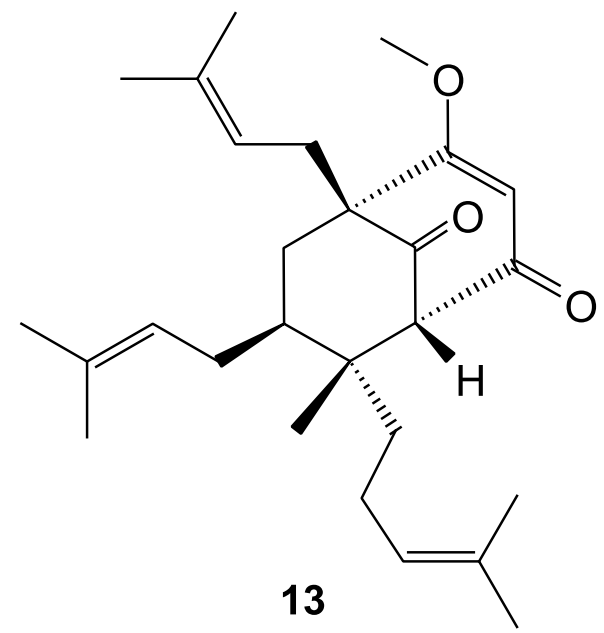




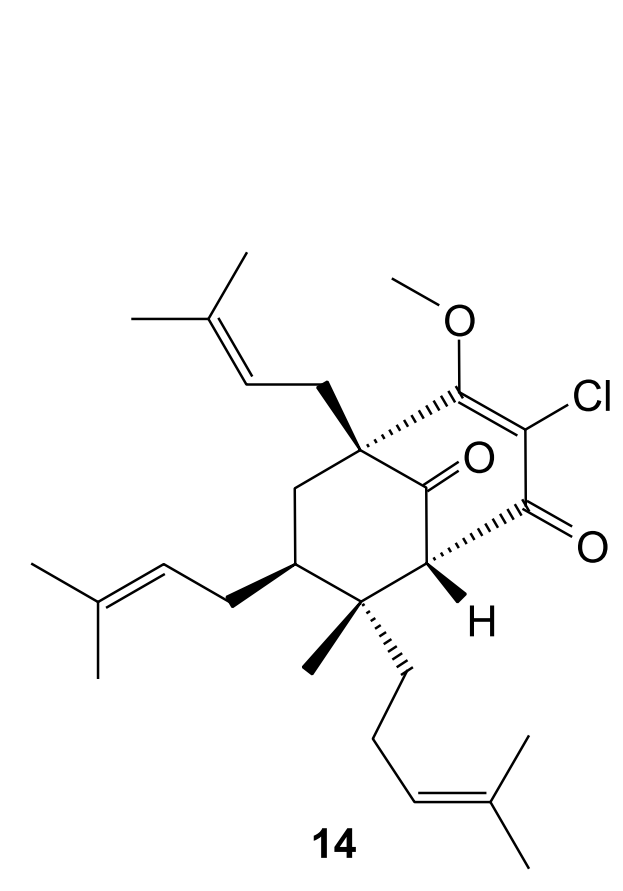



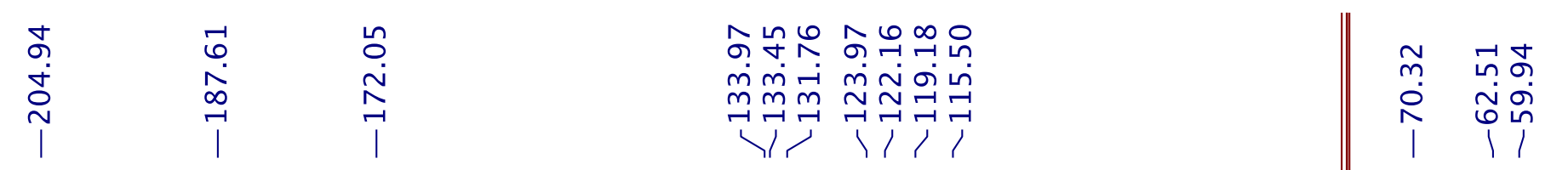

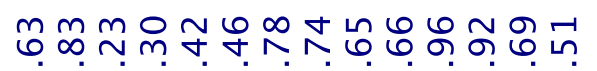
ซơmm

$-38000$

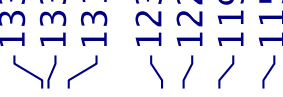
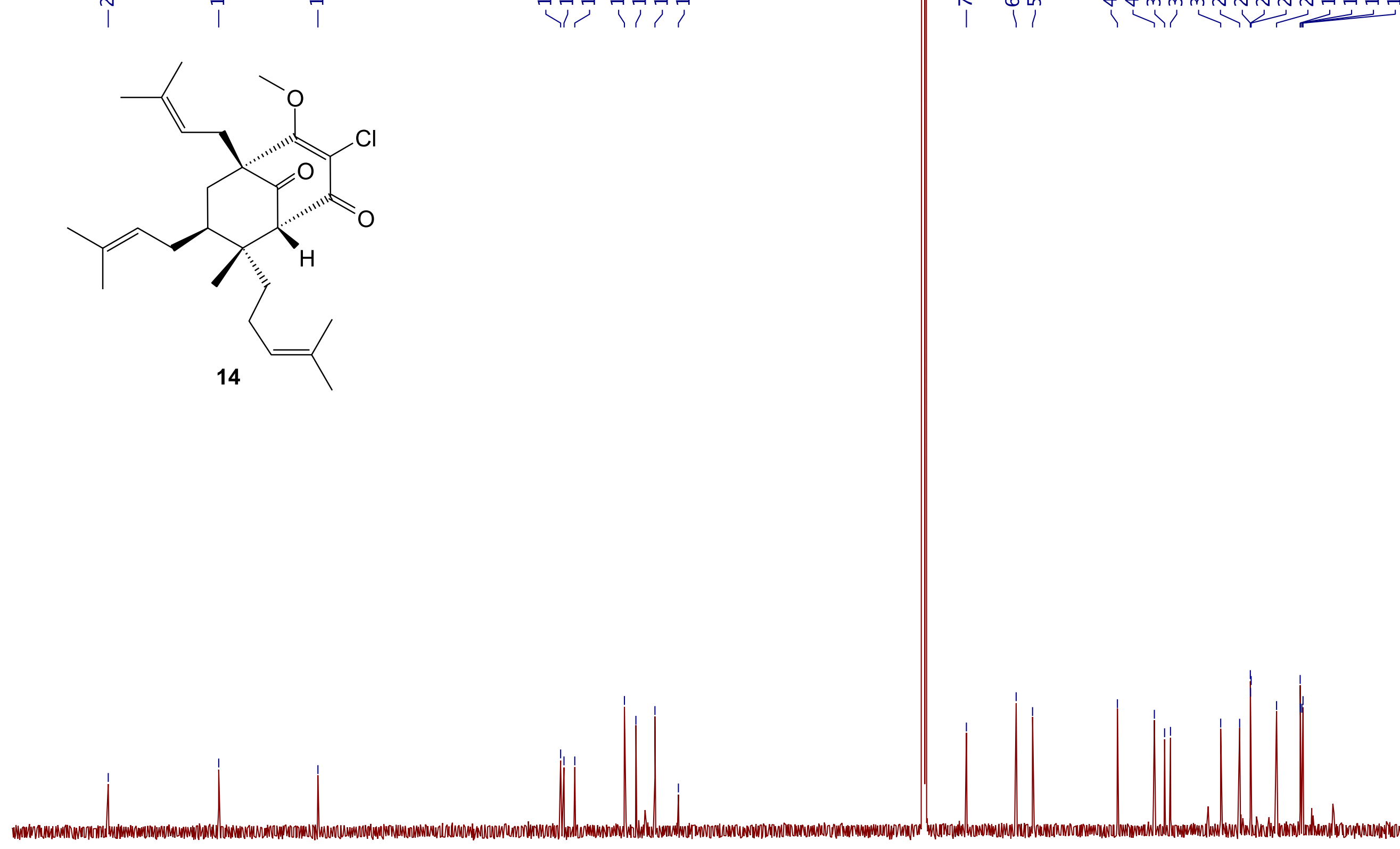

$-36000$

$-34000$

$-32000$

$-30000$

$-28000$

$-26000$

24000

$-22000$

$-20000$

$-18000$

$-16000$

$-14000$

$-12000$

$-10000$

$-8000$

$-6000$

$-4000$

$-2000$

(1)
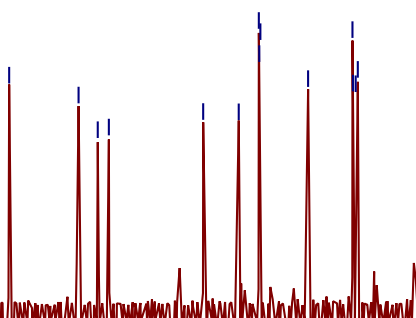


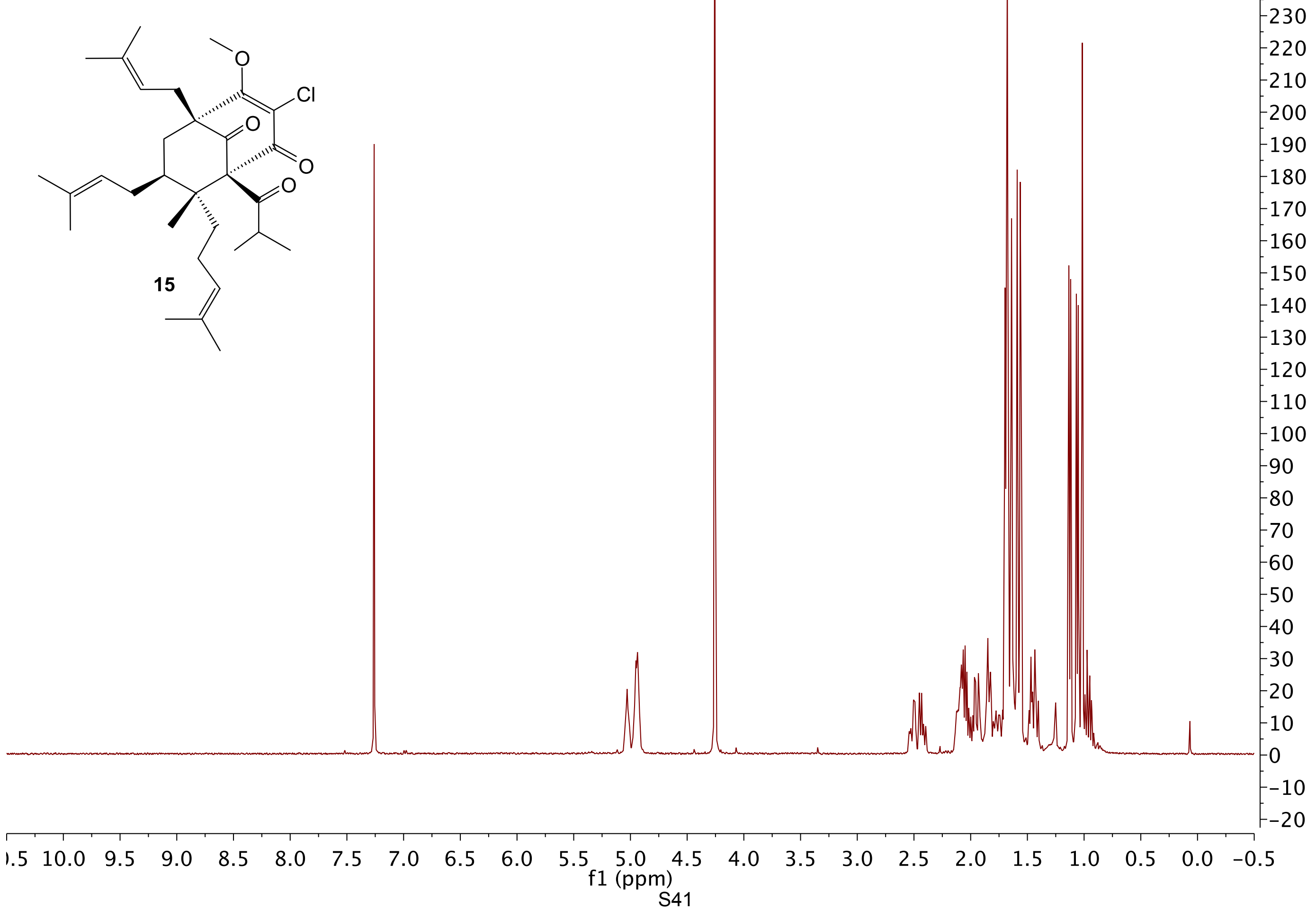




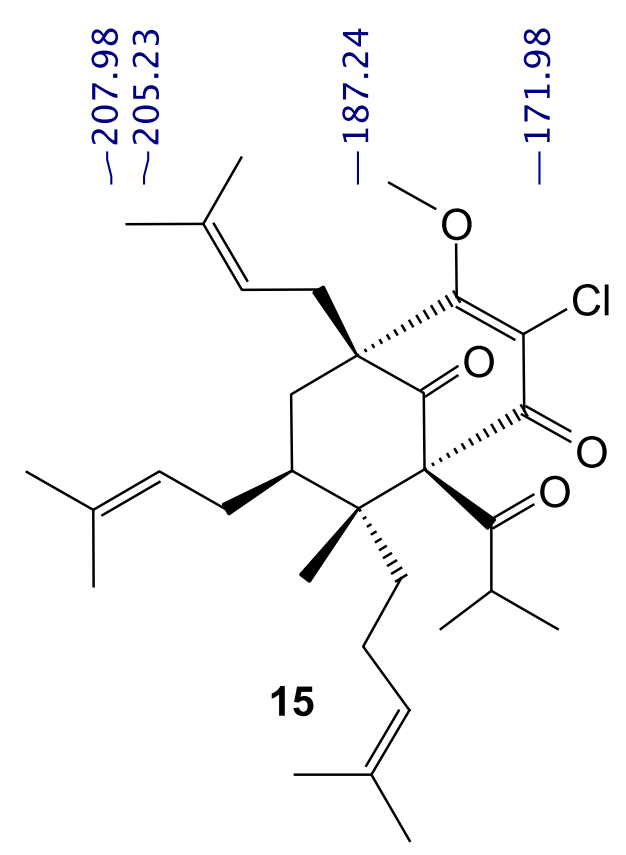

온 ำ ำกำ

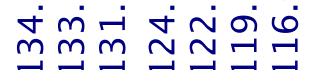

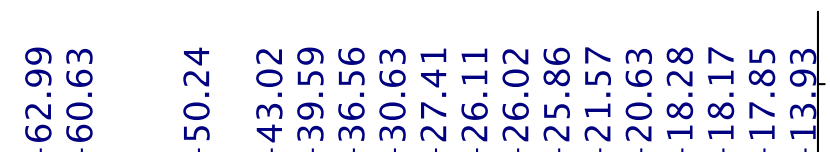

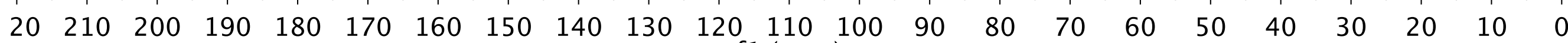




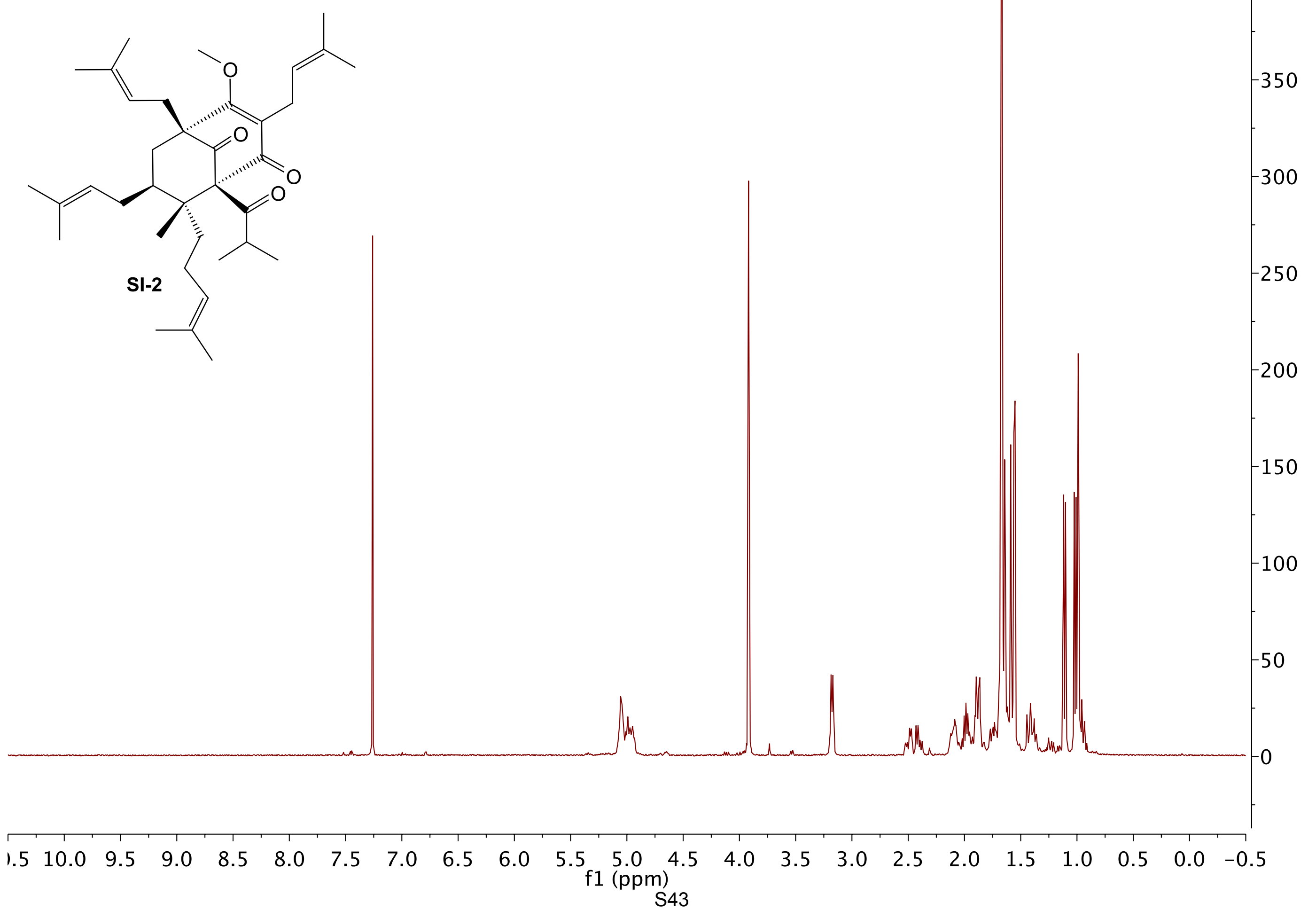




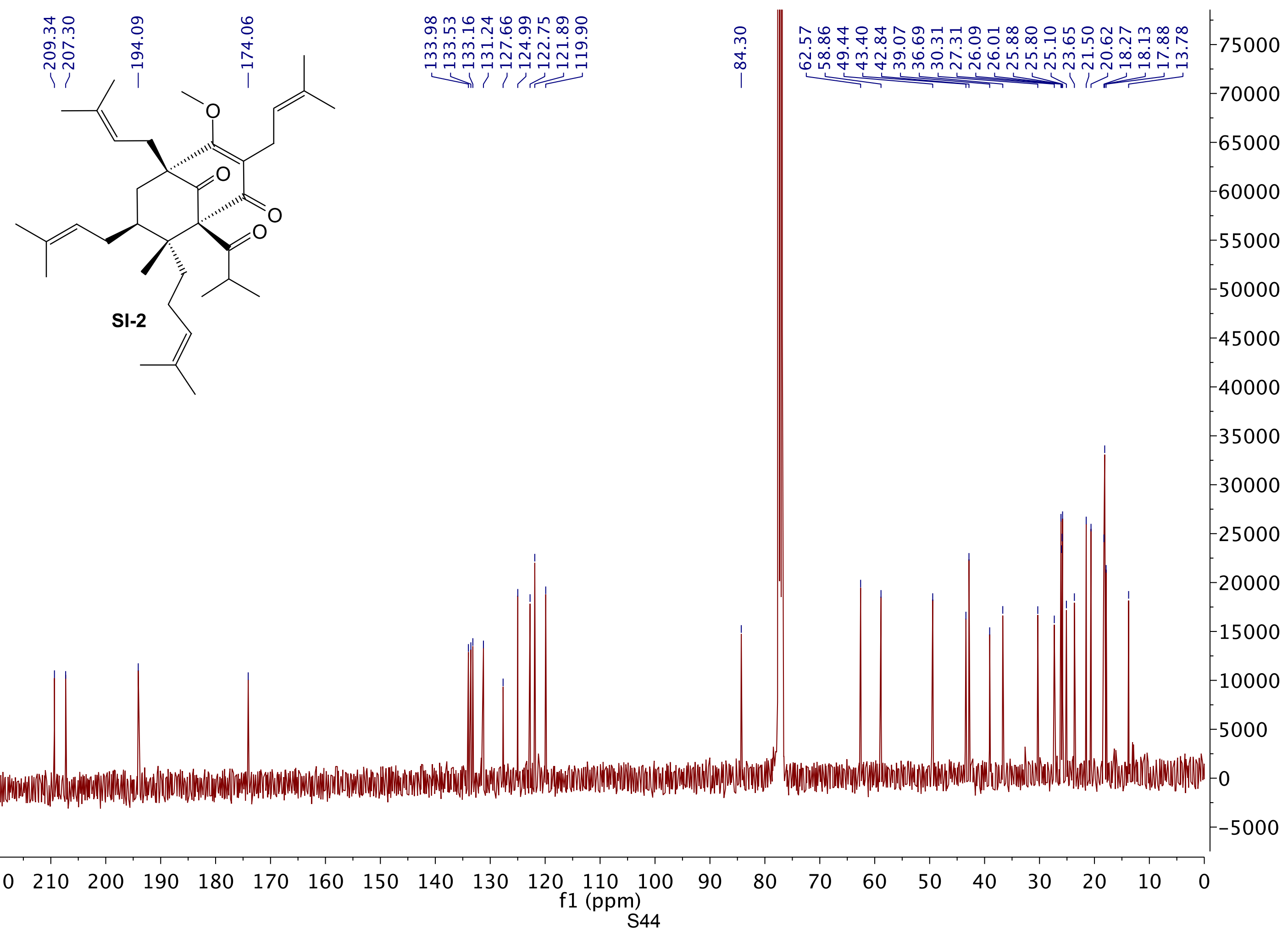




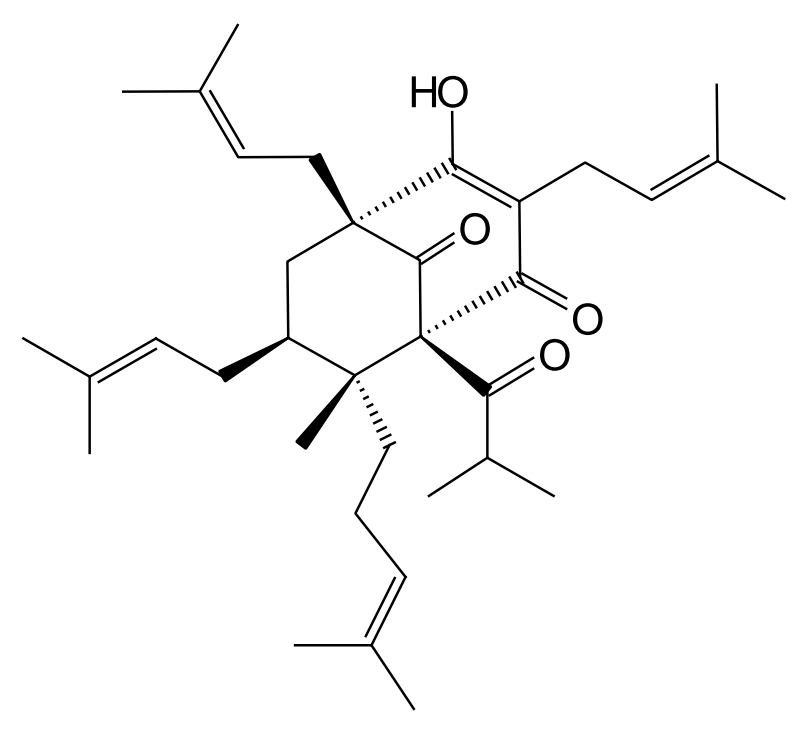

hyperforin, 1

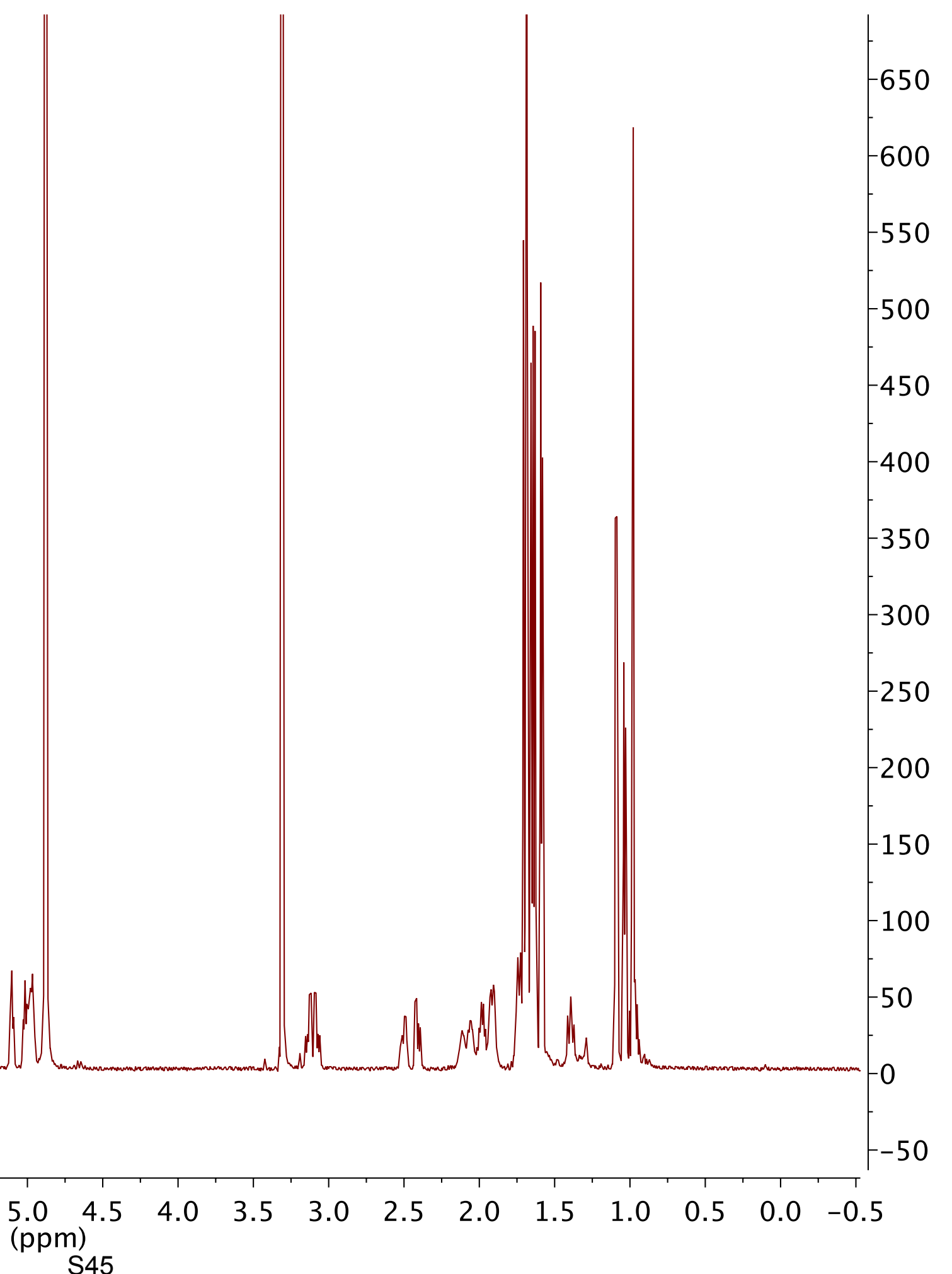




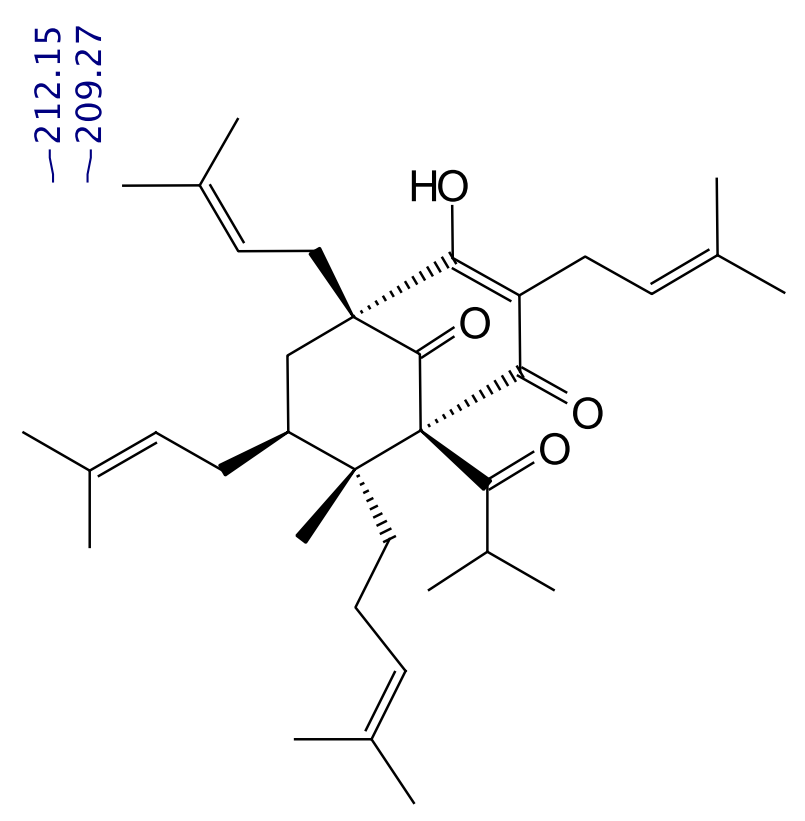

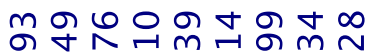

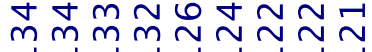

年l hyperforin, 1

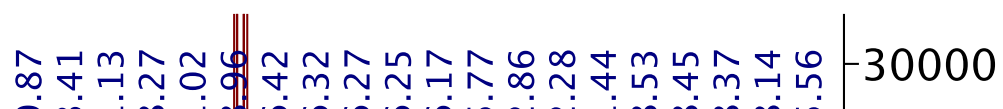

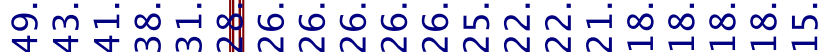

